\title{
Isolation and Characterization of Rhodanese from Bacillus licheniformis Obtained from Industrial Effluents of Steel Rolling Industry in Ilorin
}

\author{
Adeola Folashade Ehigie ${ }^{1}$, Raphael Emuebi Okonji ${ }^{2}$, Wasiu Ayinde Oladiran ${ }^{3}$ and Ona \\ Leonard Ehigie ${ }^{\# \#}$ \\ ${ }^{1,3.4}$ Department of Biochemistry, College of Health Sciences, Ladoke Akintola University of \\ Technology, Ogbomoso, Nigeria. \\ ${ }^{2}$ Department of Biochemistry, Obafemi Awolowo University, Ile-Ife, Nigeria
}

\# corresponding author.

Type of Review: Peer Reviewed.

DOl: http://dx.doi.org/10.21013/jas.v13.n2.p1

\section{How to cite this paper:}

Ehigie, A.F., Okonji, R.E., Oladiran, W.A., Ehigie , O.L. (2018). Isolation and Characterization of Rhodanese from Bacillus licheniformis Obtained from Industrial Effluents of Steel Rolling Industry in Ilorin. IRA International Journal of Applied Sciences (ISSN 2455-4499), 13(2), 14-34. doi:http://dx.doi.org/10.21013/jas.v13.n2.p1

(C) Institute of Research Advances.

\section{(cc) EY-NC}

This work is licensed under a Creative Commons Attribution-Non Commercial 4.0 International License subject to a proper citation to the publication source of the work.

Disclaimer: The scholarly papers as reviewed and published by the Institute of Research Advances (IRA) are the views and opinions of their respective authors and are not the views or opinions of the IRA. The IRA disclaims of any harm or loss caused due to the published content to any party.

Institute of Research Advances is an institutional publisher member of Publishers International Linking Association Inc. (PILA-CrossRef), USA. The institute is an institutional signatory to the Budapest Open Access Initiative, Hungary advocating the open access of scientific and scholarly knowledge. The Institute is a registered content provider under Open Access Initiative Protocol for Metadata Harvesting (OAI-PMH).

The journal is indexed \& included in CAS Source Index of Chemical Abstracts Service of American Chemical Society (USA), Index Copernicus (IC Value 85.27), WorldCat Discovery Service (USA), CrossRef Metadata Search (USA), WorldCat (USA), OCLC (USA), Open J-Gate (India), EZB (Germany) Scilit (Switzerland), Airiti (China), Bielefeld Academic Search Engine (BASE) of Bielefeld University, Germany, PKP Index of Simon Fraser University, Canada. 


\begin{abstract}
Pollution from industrial effluents and anthropogenic sources is becoming a very big ecological problem in Nigeria. A typical example of such pollutants is cyanide which can be degraded to a less toxic compound by some microorganism. Some facultative anaerobic bacteria such as Bacillus licheniformis utilizes cyanide as a substrate for survival in industrial contaminated and polluted ecosystem. This study screened for bacterial from industrial effluents in Ilorin that can synthesize rhodanese, an enzyme that can degrade cyanide to less toxic substance.
\end{abstract}

Bacillus licheniformis was isolated and biochemically characterized. Rhodanese was partially purified using $85 \%$ ammonium sulphate precipitation, ion exchange chromatography on Sephadex CM-50. The molecular weight of the enzyme was determined on a gel filtration column (Sephadex G-100) and finally on Sodium Dodecyl Sulphate Polyacrylamide Gel Electrophoresis (SDS-PAGE). The kinetic parameters $\left(\mathrm{K}_{\mathrm{m}}\right.$ and $\left.\mathrm{V}_{\max }\right)$ were determined. Statistical analysis was performed using one-way analysis of variance and results were considered significant at $\mathrm{p}<0.05$.

The result of this study showed that the optimum growth temperature for B. licheniformis was $35^{\circ} \mathrm{C}$ at a pH 9.0 while the highest duration time for the synthesis of rhodanese was 39 hours. Potassium cyanide $(\mathrm{KCN})$ and casein were the best carbon and nitrogen sources. The $B$. licheniformis isolate synthesizes rhodanese that had a specific activity of $13.63 \mathrm{RU} / \mathrm{mg}$, with a purification fold of 5.19, a percentage yield of $13.96 \%$ and an estimated native molecular weight of $34.44 \mathrm{kDa}$. The apparent $\mathrm{K}_{\mathrm{m}}$ for $\mathrm{KCN}$ and Sodium thiosulphate $\left(\mathrm{Na}_{2} \mathrm{~S}_{2} \mathrm{O}_{3}\right)$ were determined to be $32.9 \mathrm{mM}$ and $21.0 \mathrm{mM}$ respectively while their $\mathrm{V}_{\max }$ were $5.6 \mathrm{RU} / \mathrm{ml} / \mathrm{min}$ and $6.4 \mathrm{RU}$ $/ \mathrm{ml} / \mathrm{min}$ respectively. The optimum $\mathrm{pH}$ and temperature of partially purified enzyme were 8.0 and $50^{\circ} \mathrm{C}$ respectively. The enzyme showed high stability at $50^{\circ} \mathrm{C}$ for 30 minutes. The enzyme showed specificity at $6.78 \mathrm{RU} / \mathrm{ml} / \mathrm{min}$ and equally showed specificity for $\mathrm{Na}_{2} \mathrm{~S}_{2} \mathrm{O}_{3}$ while it was inhibited by other sulphur containing compounds such as 2-mercaptoethanol (2-MCPE), ammonium persulphate $\left.\left(\mathrm{NH}_{4}\right)_{2} \mathrm{~S}_{2} \mathrm{O}_{8}\right)$, and sodium metabisulphite $\left(\mathrm{Na}_{2} \mathrm{~S}_{2} \mathrm{O}_{5}\right)$. The enzyme activity was not inhibited by metal ions such as $\left(\mathrm{K}^{+}, \mathrm{Mg}^{2+}, \mathrm{Ba}^{2+}, \mathrm{Ni}^{2+}, \mathrm{Sn}^{2+}\right.$ and $\left.\mathrm{Na}^{+}\right)$at $1 \mathrm{mM}$ and $10 \mathrm{mM}$ and this was not significant ( $\mathrm{p}>0.05$ ).

The high level of expression of rhodanese in B. licheniformis suggests that the enzyme possess functional cyanide detoxification mechanism, a bioremediation process for the survival of both plants and animals in the environment. Microbial enhancement of this kind is recommended to help in reduction of toxic materials from industrial effluents.

\title{
INTRODUCTION
}

Cyanide is commonly found as a contaminant in wastewater through release from metal finishing, electroplating and coal cooking which are the crucial factors that contribute to the bulk occurrence of cyanide in the environment (Dash et al., 2009). In its gaseous form, it associates with a hydrogen ion to form hydrogen cyanide, an extremely toxic gas that smells slightly like almonds. Cyanide, in its solid form, is combined with various metal ions such as potassium and sodium to form white crystalline substances, which are stable. It was hypothesized that cyanide was the first organic compound on earth, from which chemical compounds are formed (Oparin, 1957; Rawls, 1997; Parmar et al., 2012).

Cyanide is a natural compound produced by many organisms, including bacteria, algae, fungi, and plants, and is bio-produced in some cases as a defensive metabolite (Dubey and Holmes, 1995) or with invasive purposes (Pessi and Haas, 2004). Plants are the main source of cyanide in the biosphere because they co-generate cyanide with ethylene (Zagrobelny et al., 2008) in addition to generating cyanoglycosides and cyanolipids. Many microorganisms can use potassium or sodium cyanide as a sole source of carbon and nitrogen.

Rhodanese (thiosulphate cyanide sulphurtransferase: EC 2.8.1.1) is an ubiquitous enzyme that is in vitro catalyses the transfer of a sulphur atom from suitable donors to nucleophilic acceptors by way of a double displacement mechanism. During the catalytic process the enzyme cycles between a sulphur-free and a persulfidecontaining form, via formation of a persulfide linkage to a catalytic cysteine residue (Domenico et al., 2000). Several biological functions have been attributed to this ubiquitous enzyme which include cyanide detoxification 
(Agboola and Okonji, 2004), construction of iron-sulphur centres in proteins (Ugulava et al., 2000); selenium metabolism (Ray et al., 2000); Thioredoxin metabolism (Nandi et al., 2000); and also in sulphur supplier for key enzymes in sulphur energy metabolism (Aussignargues et al., 2012).

\begin{tabular}{|c|c|}
\hline $\mathrm{S}_{2} \mathrm{O}_{3}{ }^{2-}+$ & \\
\hline hiosulphate ion & Cyanide ion \\
\hline
\end{tabular}

\section{MATERIALS AND METHODS}

Potassium cyanide, sodium thiosulphate, peptone, yeast extract, boric acid, sodium borate, formaldehyde, ferric nitrite, nitric acid, citric acid, sodium citrate, ammonium sulphate (enzyme grade), potassium chloride and sodium chloride were obtained from BDH Chemical Limited, Poole, England. Glycerol, Coomassie Brilliant-Blue, Blue Dextran and Bovine Serum Albumin (BSA) were obtained from Sigma Chemical Company, St. Loius, Mo., USA. Sephadex CM-50 was obtained from Pharmacia Fine Chemical, Uppsala, Sweden. Disodium hydrogen phosphate and monosodium dihydrogen phosphate were products of Kermel Reagent Company Limited, Tianjin, China. and ammonium persulphate were products of Feinbiochemica, Heidelberg, Germany. Biogel P-100 was purchased from Bio-Rad Laboratories Inc., Benicia Ca., USA. Other chemicals, solvents and media ingredients used for the experimental purpose were of analytical grade and were procured from reputed chemical firms.

\section{Sample Collection}

Three (3) different $200 \mathrm{ml}$ sterile bottles were used in collection of the effluents samples from three (3) different sections of the steel rolling industry. The samples were taken straight to the laboratory for microbiological analysis.

\section{Enzyme and protein assays}

Rhodanese activity was measured according to the method of Lee et al., (1995), as described by Agboola and Okonji (2004), on the principles of the colorimetric determination of thiocyanate formation. The reaction mixture consists of $0.5 \mathrm{ml}$ of $50 \mathrm{mM}$ Borate buffer ( $\mathrm{pH} 9.4$ ), $0.2 \mathrm{ml}$ of $250 \mathrm{mM} \mathrm{KCN}, 0.2 \mathrm{ml}$ of $250 \mathrm{mM} \mathrm{Na}_{2} \mathrm{~S}_{2} \mathrm{O}_{3}$, and $0.1 \mathrm{ml}$ of the enzyme solution in a total of volume of $1.0 \mathrm{ml}$. The mixture was incubated for 1 minute at room $37^{\circ} \mathrm{C}$ and the reaction was stopped by adding $0.5 \mathrm{ml}$ of $15 \%$ formaldehyde, followed by the addition of $1.5 \mathrm{ml}$ of Sorbo reagent. The absorbance was taken at $460 \mathrm{~nm}$. One Rhodanese Unit (RU) was defined as the amount of the enzyme that will convert one micro-mole $(1 \mu \mathrm{mol})$ of cyanide to thiocyanide in one minute at $37^{\circ} \mathrm{C}$ (Sorbo, 1951). The controls contained the reaction mixture as described above but does not have any enzyme. The enzyme was replaced with $0.1 \mathrm{ml}$ distilled water, the mixture was incubated for 1 minute at $37^{\circ} \mathrm{C}$ and the reaction was stopped by adding $0.5 \mathrm{ml}$ of $15 \%$ formaldehyde, followed by the addition of $1.5 \mathrm{ml}$ of Sorbo reagent. The absorbance was taken at $460 \mathrm{~nm}$. Protein concentrations were determined by the method of Bradford (1976) using bovine serum albumin (BSA) as the standard.

\section{Enzyme isolation and purification}

A millilitre of the water sample was taken from each of the sample bottle into a test tube containing $9 \mathrm{ml}$ of sterile distilled water. Serial dilution was carried out to thin out the load of microorganisms to be plated. Serial dilution up to $10^{-9}$ was carried out and dilution 7, 8 and 9 were pour plated. The plating was done by taking one millilitre of each of the dilution into separate petri dishes under aseptic condition and cooled but molten sterile nutrient agar was poured into each petri dishes, swirled to ensure proper mixing and distribution of the sample and the media. The media in the petri dishes were left to cool and set. The plates were incubated in an inverted position at $37^{\circ} \mathrm{C}$ for 48 hours. All plates were labeled appropriately. After 48 hours the plates were observed and the ones with the most distinct colonies were aseptically picked using a sterile inoculating loop and then streaked on a different sterile petri dishes containing solid sterile nutrient agar. The streaking was done near a flame to prevent contamination of the sterile solidified nutrient agar plates. After streaking, the plates were covered, inverted, labeled and incubated at $37^{\circ} \mathrm{C}$ for 24 hours. This process was repeated until pure colonies of each isolates were obtained. 
The different isolates obtained were transferred into nutrient agar slants and then incubated for 24 hours to ensure growth of the organism. After 24 hours it was kept in a refrigerator to arrest growth and store the isolates.

\section{Ammonium Sulphate Precipitation}

The supernatant obtained from the centrifugation of the crude homogenate was brought to $85 \%$ ammonium sulphate saturation i.e $25.5 \mathrm{~g}$ of ammonium sulphate (analytical grade) was added and stirred slowly to $50 \mathrm{ml}$ of crude enzyme. This was done for 1 hour with occasional stirring until all the salt had dissolved completely in the supernatant. The mixture was left overnight in the fridge, followed by centrifugation at 12,000 rpm for $30 \mathrm{~min}$ at $10^{\circ} \mathrm{C}$. The supernatant was discarded and precipitate was collected and suspended in $0.1 \mathrm{M}$ Phosphate buffer $\mathrm{pH} 6.5$. It was evaluated for rhodanese activity as described in section 3.11, the protein content was determined using the method of Bradford 1976.

\section{Ion-Exchange Chromatography on CM-Sephadex C-50}

CM-Sephadex C-50 cation exchanger was pre-treated by boiling twenty grams ( $30 \mathrm{~g})$ of the resin in $300 \mathrm{ml}$ distilled water for $1 \mathrm{hr}$. This was followed by the addition of $100 \mathrm{ml} 0.1 \mathrm{M} \mathrm{HCl}$ for $30 \mathrm{mins}$, after which the acid was decanted and the resin was washed with distilled water several times to ensure the total removal of the acid. Thereafter $100 \mathrm{ml}$ of $0.1 \mathrm{M} \mathrm{NaOH}$ was added to the resin, which was decanted after 30 mins, followed by the thorough rinsing of the resin with distilled water to remove all traces of the base. The resin was then equilibrated with $0.1 \mathrm{M}$ phosphate buffer ( $\mathrm{pH}$ 6.5) before it was packed into a $2.5 \times 40 \mathrm{~cm}$ column. Five millilitres (10 ml) of the enzyme solution from the preceding step was then applied on the column. The column was washed with $100 \mathrm{ml}$ of $0.5 \mathrm{M} \mathrm{Nacl}$ to remove unbound protein, followed by elution with $150 \mathrm{ml}$ of $1.0 \mathrm{M} \mathrm{NaCl}$ in the same buffer. Fractions of $5 \mathrm{ml}$ were collected from the column at a rate of $20 \mathrm{ml}$ per hr. The fractions were assayed for rhodanese activity as described in section 3.11. The active fractions from the column were pooled and dialyzed against $50 \%$ glycerol in $0.1 \mathrm{M}$ phosphate buffer, $\mathrm{pH} 6.5$. The yield and fold of purifications were calculated.

\section{Gel Filteration Chromatography on Sephadex G-100}

Gel filteration chromatography separate proteins and other molecules based on their molecular sizes. The Sephadex G-100 resin was swollen by dissolved 20g of the matrix in $200 \mathrm{ml}$ of distilled water and boiled for 1 hour at $100{ }^{\circ} \mathrm{C}$ as described by Okonji et al. (2010a). The swollen gel was left overnight at $4{ }^{\circ} \mathrm{C}$. The gel was then loaded and equilibrated on a $2.5 \mathrm{~cm} \times 90 \mathrm{~cm}$ column. $7 \mathrm{ml}$ of the dialysate from the previous step was loaded on the column and $2 \mathrm{ml}$ of fractions were collected at $20 \mathrm{ml} /$ hour. The rhodanese activity and protein concentration were monitored and the active fractions were pooled

\section{Determination of Native Molecular Weight}

The native molecular weight was determined on a Sephadex G-100 column $(2.5 \mathrm{x} 90 \mathrm{~cm})$. The standard proteins used to calibrate the column were bovine serum albumin $\left(\mathrm{M}_{\mathrm{r}} 66000\right.$ Dalton; $\left.10 \mathrm{mg} / \mathrm{ml}\right)$, ovalbumin ( $\mathrm{M}_{\mathrm{r}} 45000$ Dalton; $\left.10 \mathrm{mg} / \mathrm{ml}\right)$ and $\alpha$-chymotrypsinogen $\left(\mathrm{M}_{\mathrm{r}} 25,000\right.$ Dalton; $\left.10 \mathrm{mg} / \mathrm{ml}\right)$. The protein standards were prepared in $0.1 \mathrm{M}$ Phosphate buffer $\mathrm{pH}$ 6.5. Total sample volume of each of the protein markers applied to the column was $10 \mathrm{ml}$. The proteins were eluted with phosphate buffer $\mathrm{pH} 6.5$. Fractions of $5 \mathrm{ml}$ were collected and monitored by measuring absorbance at $280 \mathrm{~nm}$ for the protein. The void volume $\left(\mathrm{V}_{\mathrm{o}}\right)$ of the column was determined by the elution volume $\left(\mathrm{V}_{\mathrm{e}}\right)$ of Blue dextran $(5 \mathrm{mg} / \mathrm{ml})$. A $10 \mathrm{ml}$ aliquot of the enzyme solution was then applied to the same column and the elution volume of the rhodanese was determined. The partition coefficient $\left(\mathrm{K}_{\mathrm{av}}\right)$ of each of the standard proteins and the purified rhodanese was calculated. A plot of logarithm of the molecular weight of the marker proteins against $\mathrm{K}_{\mathrm{av}}$ (partition coefficient) was made. The molecular weight of the enzyme was then extrapolated from the curve.

$$
\mathrm{K}_{\mathrm{av}}=\mathrm{V}_{\mathrm{e}}-\mathrm{V}_{\overline{\mathrm{o}}} \overline{\mathrm{V}_{\mathrm{t}}-\mathrm{V}_{\mathrm{o}}}
$$

$\begin{array}{lll}\text { Where; } & & \\ \mathrm{V}_{\mathrm{e}} & = & \text { elution volume } \\ \mathrm{V}_{\mathrm{o}} & = & \text { void volume } \\ \mathrm{V}_{\mathrm{t}} & = & \text { total volume }\end{array}$




\section{Determination of Subunit Molecular Weight}

Sodium dodecyl sulphate polyacrylamide gel electrophoresis (SDS-PAGE) was carried out according to the method of Weber and Osborn (1975) to determine the subunit molecular weight of the enzyme on a 10\% slab gel apparatus with a notched glass plate. Gels of $1.5 \mathrm{~mm}$ thickness were prepared by using perplex spacers of same size. Standard proteins were as contained in Molecular Weight Markers Calibration Kit for SDS polyacrylamide gel electrophoresis. The standard molecular weight markers includes Bovine serum albumin (66.0 kDa), Ovalbumin $(45.0 \mathrm{kDa})$, Chymotrypsin $(25 \mathrm{kDa})$ and Lysozyme (14.3 kDa).

\section{Determination of kinetic parameters}

The kinetic parameters $\left(\mathrm{K}_{\mathrm{m}}\right.$ and $\left.\mathrm{V}_{\max }\right)$ of the enzyme were determined by varying concentrations of $0.25 \mathrm{M}$ $\mathrm{KCN}$ between $0.005 \mathrm{M}$ and $0.05 \mathrm{M}$ at fixed concentration of $0.25 \mathrm{M} \mathrm{Na} \mathrm{S}_{2} \mathrm{O}_{3}$. Also, the concentration of $0.25 \mathrm{M}$ $\mathrm{Na}_{2} \mathrm{~S}_{2} \mathrm{O}_{3}$ was varied between $0.005 \mathrm{M}$ and $0.05 \mathrm{M}$ at fixed concentration of $0.25 \mathrm{M} \mathrm{KCN}$. Plots of the reciprocal of initial reaction velocity $(1 / \mathrm{V})$ versus reciprocal of the varied substrates $1 /[\mathrm{S}]$ at each fixed concentrations of the other substrate were made according to Lineweaver and Burk (1934).

\section{Effect of pH on the Activity of Partially Purified Rhodanese}

The effect of $\mathrm{pH}$ on the enzyme activity was performed according to the methods of Agboola and Okonji (2004). The enzyme was assayed using $50 \mathrm{mM}$ citrate buffer (pH 3-5); $50 \mathrm{mM}$ phosphate buffer (6-8) and 50mM borate buffer $(\mathrm{pH} 3-11)$. The different buffers of different $\mathrm{pH}$ were substituted with the reaction buffer of the rhodanese assay.

\section{Effect of Temperature on the Activity of Partially Purified Rhodanese}

The enzyme was assayed at temperatures between $30^{\circ} \mathrm{C}$ and $80^{\circ} \mathrm{C}$ at an interval of $10^{\circ} \mathrm{C}$ to investigate the effect of temperature on the activity of the enzyme and to determine the optimum temperature of the enzyme. The assay mixture was first incubated at the indicated temperature for $10 \mathrm{~min}$ before addition of an aliquot of the enzyme which had been equilibrated at the same temperature. The control test contains distilled water instead of enzyme.

\section{Effect of Heat at Different Temperatures on Partially Purified Rhodanese Activity}

The heat stability of the enzyme was determined by incubating $2 \mathrm{ml}$ of the enzyme for $1 \mathrm{~h}$ at $30^{\circ} \mathrm{C}, 40^{\circ} \mathrm{C}$, $50^{\circ} \mathrm{C}$ and $60^{\circ} \mathrm{C}$ respectively. From the incubated solution, $0.1 \mathrm{ml}$ was withdrawn at $10 \mathrm{~min}$ interval and assayed for residual activity. The activity at $40^{\circ} \mathrm{C}, 50^{\circ} \mathrm{C}$ and $60^{\circ} \mathrm{C}$ was expressed as a percentage of the activity of the enzyme incubated at $30^{\circ} \mathrm{C}$ which was the control. The residual activity of the enzyme was determined. The residual rhodanese activity was plotted against the different temperatures.

\section{Effect of Metal Ions on Partially Purified Rhodanese Activity}

The method of Lee et al., (1995) was used to study the effect of various metal ions (cations) on the activity of partially purified rhodanese. The salts of the cations include $\mathrm{MgCl}_{2}, \mathrm{CaCl}_{2}, \mathrm{HgCl}_{2}, \mathrm{NaCl}, \mathrm{BaCl}_{2}$ and $\mathrm{KCl}$ and at concentrations of $1.0 \mathrm{mM}$ and $10 \mathrm{mM}$. A typical enzyme assay with $1 \mathrm{ml}$ of reaction mixture contained $0.5 \mathrm{ml} 50$ $\mathrm{mM}$ borate buffer $\mathrm{pH} 9.4,0.2 \mathrm{ml}$ of $250 \mathrm{mM} \mathrm{KCN}, 0.2 \mathrm{ml}$ of $250 \mathrm{mM} \mathrm{Na}_{2} \mathrm{~S}_{2} \mathrm{O}_{3}, 0.05 \mathrm{ml}$ of the respective salt solution. The substrate was mixed with the $0.05 \mathrm{ml}$ of each metal concentration, followed by the addition of $0.05 \mathrm{ml}$ enzyme. The mixture was incubated for one minute at room temperature, followed by the addition of $0.5 \mathrm{ml} 15 \%$ formaldehyde and $1.5 \mathrm{ml}$ sorbo reagent. The control of each metal concentration did not contain metal.

\section{Substrate specificity and kinetics}

The substrate specificity of the enzyme will be determined by using different sulphur containing compounds such as sodium sulphite, 2-mercaptoethanol, ammonium persulphate, ammonium sulphate and sodium metabisulphite in a typical rhodanese assay mixture. The different sulphur compounds were substituted in place of sodium thiosulphate. The activity was taken as described in section 3.11. The activity will be expressed as a percentage activity of the enzyme using sodium thiosulphate as the control. 


\section{Results}

\section{Isolation of Bacteria and Screening of Isolates For Rhodanese Production}

Ten bacteria were obtained from the water samples obtained from the steel rolling industry. The isolates were screened for their ability to produce rhodanese using the basal medium as described in section 3.8 , the isolate with maximum rhodanese activity was selected for further studies. The isolate with the best activity was identified using microbiology procedure. Figure 1 shows the screening of the different isolates.

\section{Identification of Rhodanese Producing Bacteria}

The morphological characteristics of the isolate observed on nutrient agar plate after $24 \mathrm{hr}$ incubation at $35^{\circ} \mathrm{C}$ is presented in Table 1 . Also, the Gram's reaction, spore staining test and other biochemical characteristics of the selected isolate was presented in Table 2 and the presumptive identity was based on comparison with Bergey's Manual of Determinative bacteriology (Buchanan and Gibbon, 1974) to be Bacillus licheniformis. The isolate appeared as flat, translucent colonies on agar plates. When Gram stained film was examined, the isolate appeared as gram positive rods.

Table 1. Morphological Characteristics of Isolates

$\begin{array}{lc}\text { Isolate } & \text { A5 } \\ \text { Shape } & \text { Rod } \\ \text { Surface } & \text { Glistering } \\ \text { Opacity } & \text { Opaque } \\ \text { Elevation } & \text { Flat } \\ \text { Colour } & \text { Cream }\end{array}$

Table 2. Gram's Staining, Spore staining, and Biochemical Characteristics of the Isolate

Isolate code

Gram's Reaction
Shape
Catalase
Starch Hydrolysis
Spore Staining
$\mathrm{NO}_{3}{ }^{-}$Reduction
Citrate
$6.5 \% \mathrm{NaCl}$
$\mathrm{MR} / \mathrm{VP}$
Glucose
Size
Indole
Motility
Sulphur
Presumptive Identity

A5

Positive

Rod

Positive

Positive

Positive

Negative

Negative

Positive

Positive/Positive

Positive

0.6-1.0nm in length

Negative

Positive

Negative

Bacillus sp.

\section{Growth and Rhodanese Production}

The result in Figure 1 showed the screening of the different bacterial isolates. The result as presented in figure 2 showed the time course of rhodanese production by Bacillus licheniformis. Maximum production was obtained at $39^{\text {th }}$ hour with rhodanese activity of $3.09 \mathrm{RU} / \mathrm{ml} / \mathrm{min}$. 


\section{Effect of Carbon Sources on Production of Rhodanese by Bacillus licheniformis}

The production of rhodanese was discovered to be highest with $\mathrm{KCN}$ as the sole carbon source with enzyme activity of $3.142 \mathrm{RU} / \mathrm{ml} / \mathrm{min}$ as presented in figure 4 while maltose gave the least value of $0.618 \mathrm{RU} / \mathrm{ml} / \mathrm{min}$.

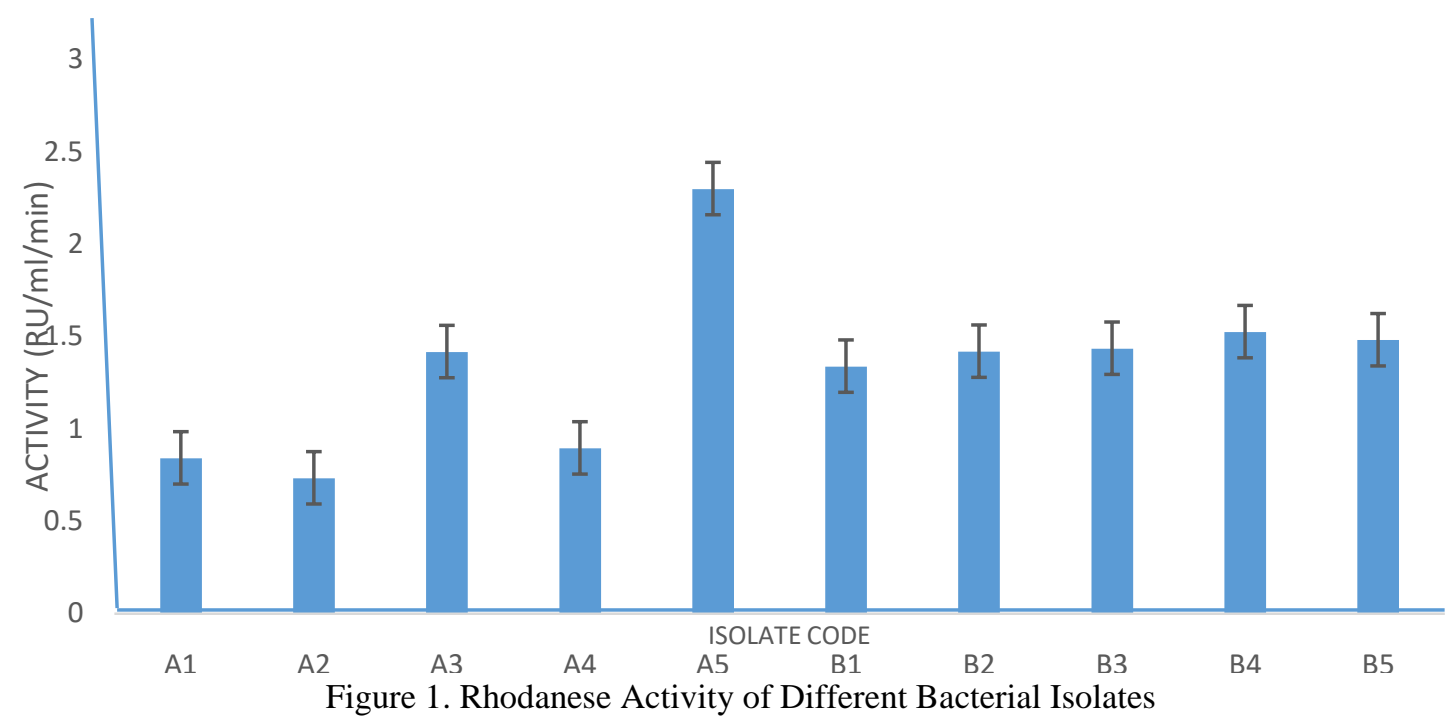

ISOLATE CODE

$\mathrm{A} 1=\mathrm{C}$. kutseri

$\mathrm{A} 2=\mathrm{B}$. cereus

$\mathrm{A} 3=\mathrm{B}$. macerans

$\mathrm{A} 4=\mathrm{B}$. subtilis

$\mathrm{A} 5=\mathrm{B}$. licheniformis

$\mathrm{B} 1=\mathrm{B}$. macquariensis

$\mathrm{B} 2-\mathrm{B} 5=$ Aeromonas spp

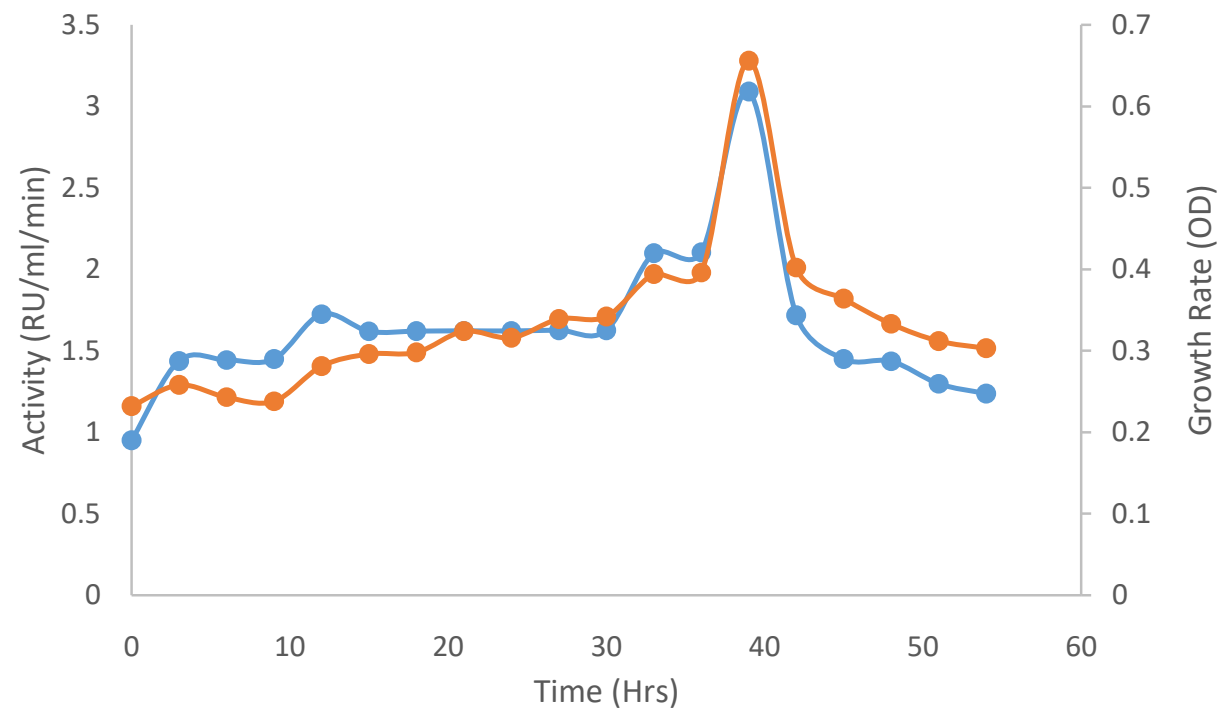

Figure 2. Incubation Time on Rhodanese Production and Cell Growth 


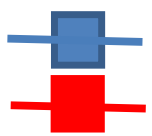

Growth Rate (OD)

Rhodanese Activity

Different Concentrations of Potassium Cyanide on Rhodanese Production by Bacillus licheniformis

The effect of different concentrations of $\mathrm{KCN}$ showed that rhodanese production was highest at $\mathrm{KCN}$ concentration of $0.8 \mathrm{~g}(\mathrm{w} / \mathrm{v})$ and least with $\mathrm{KCN}$ concentration of $0.1 \mathrm{~g}(\mathrm{w} / \mathrm{v})$ with rhodanese activity of 3.344 $\mathrm{RU} / \mathrm{ml} / \mathrm{min}$ and $3.232 \mathrm{RU} / \mathrm{ml} / \mathrm{min}$ respectively as shown in Figure 5.

\section{Influence of Different Nitrogen Sources on Rhodanese Production by Bacillus licheniformis}

The effect of different sources of nitrogen was studied by varying only the nitrogenous components of the media. Casein gave the highest activity with rhodanese activity of $3.674 \mathrm{RU} / \mathrm{ml} / \mathrm{min}$ as shown in Figure 6 and 7 respectively.

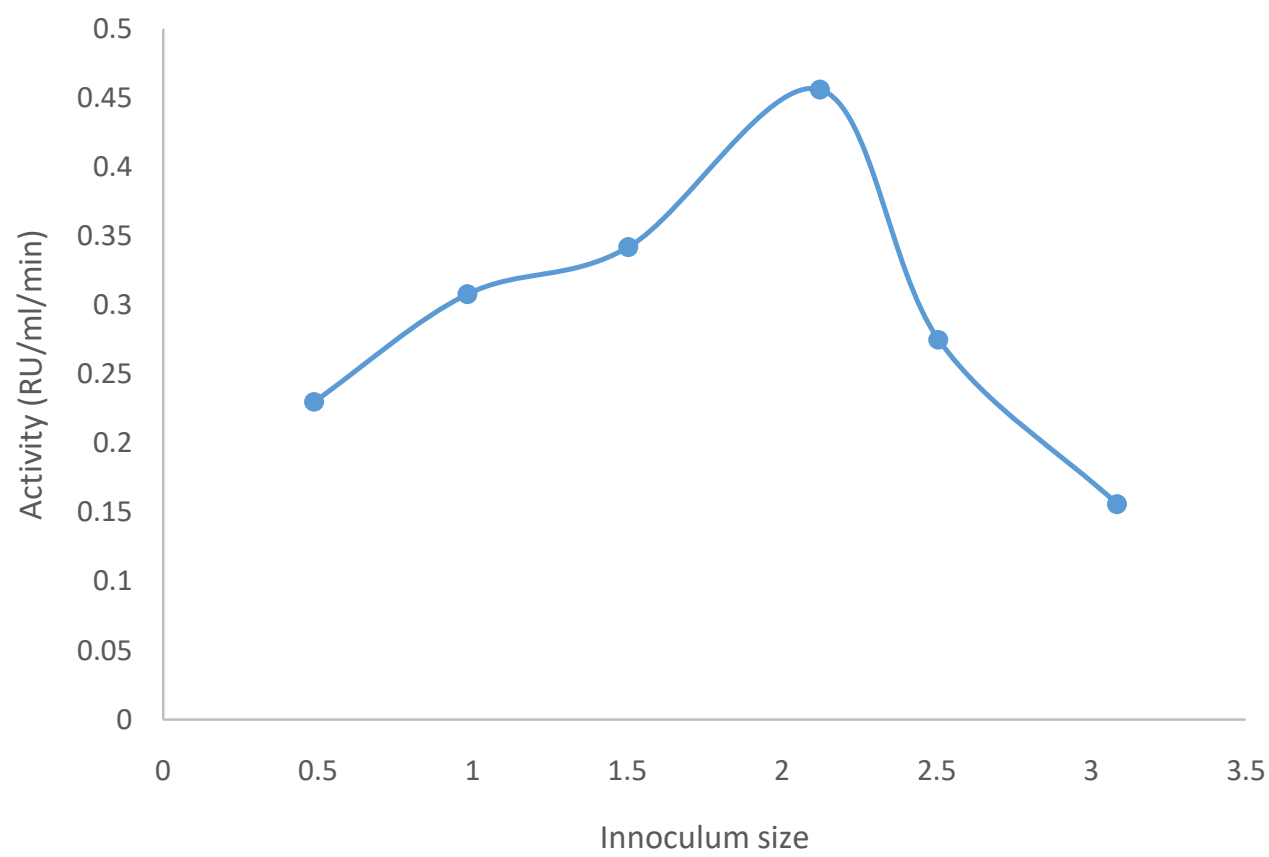

Figure 3. Inoculum size per 100ml of Basal Medium on Rhodanese Production by Bacillus licheniformis 


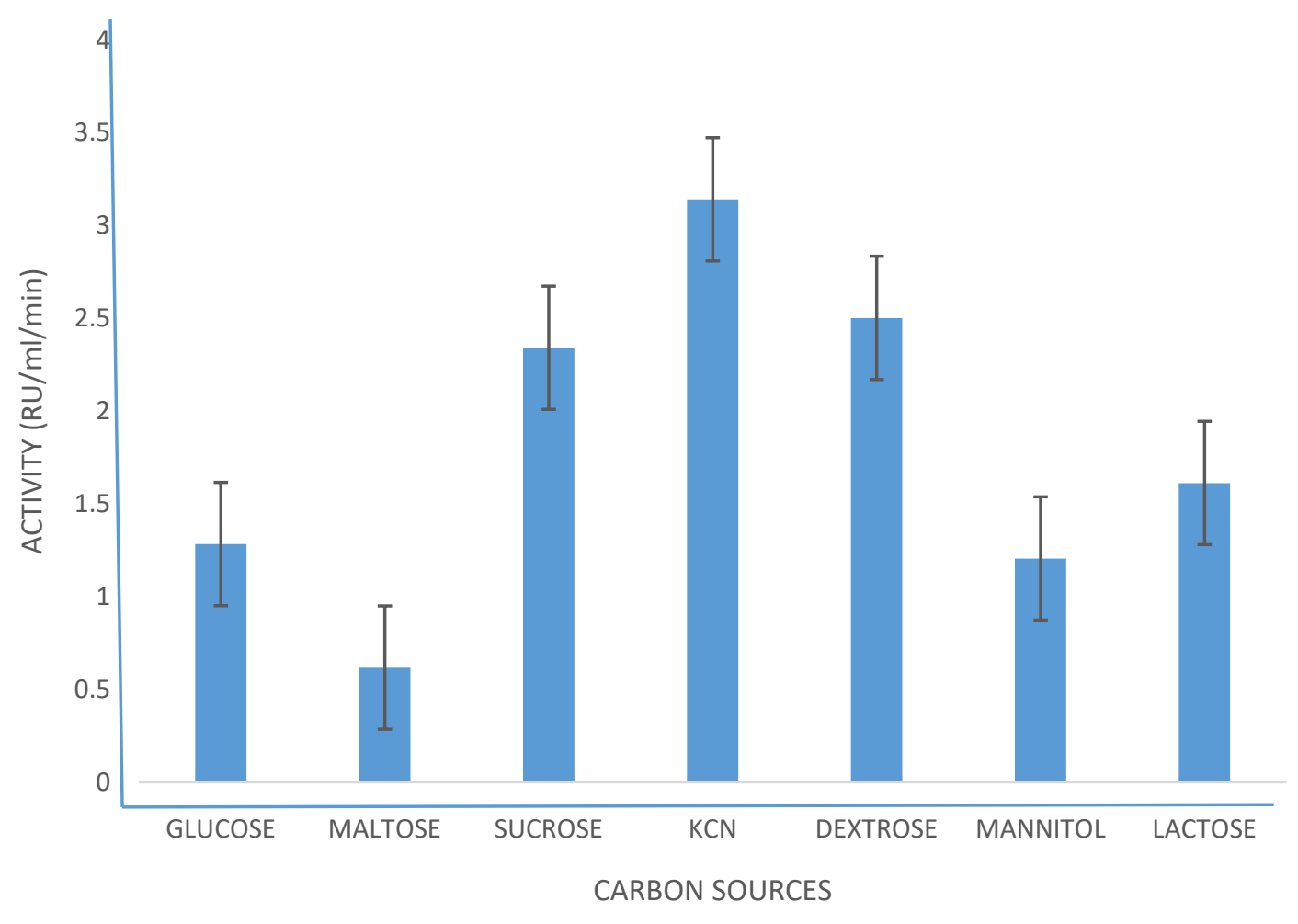

Figure 4. Effect of Different Carbon Sources on Rhodanese Production by Bacillus licheniformis

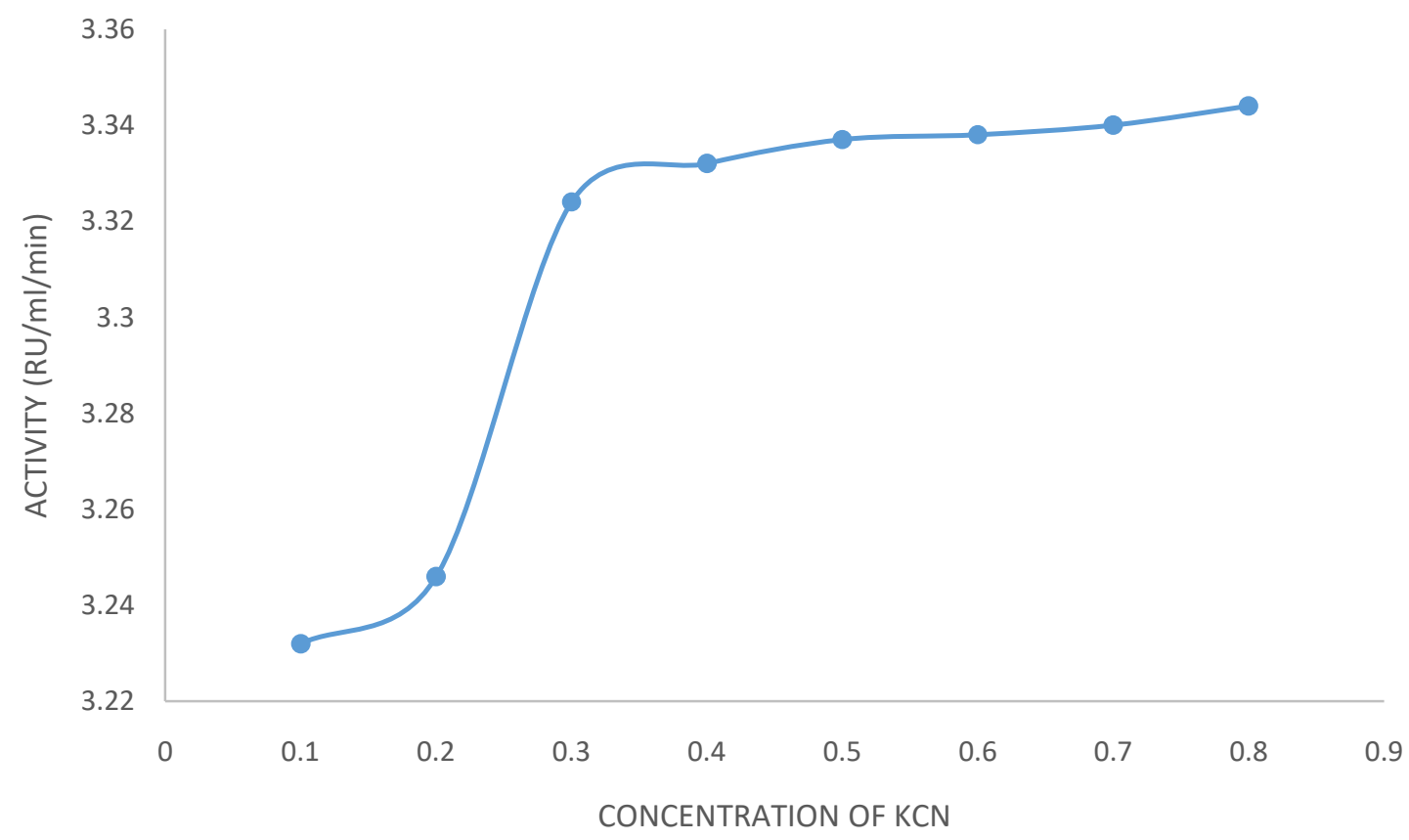

Figure 5. Effect of Different Concentrations of KCN on Rhodanese Production by Bacillus licheniformis 


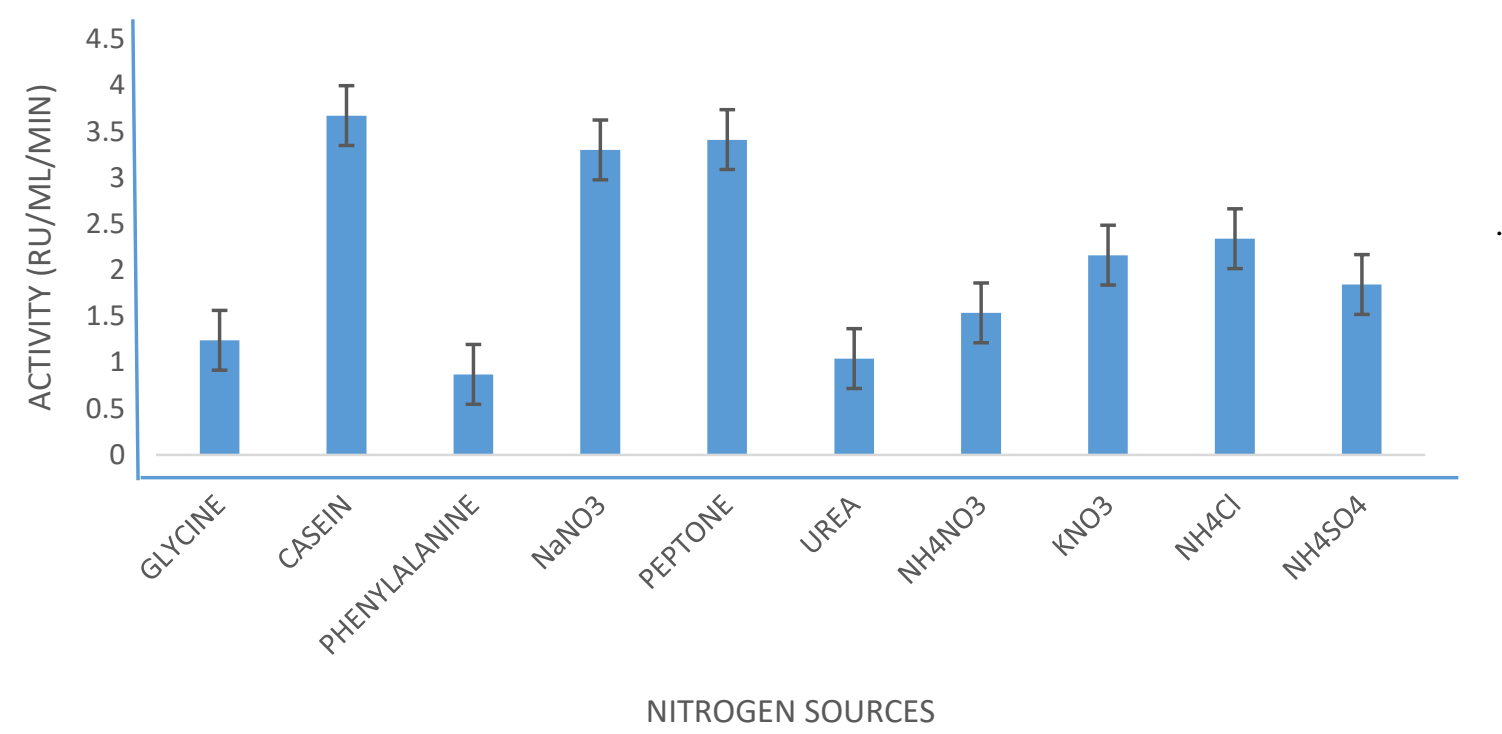

Figure 6. Different Nitrogen Sources on Rhodanese Production by Bacillus licheniformis

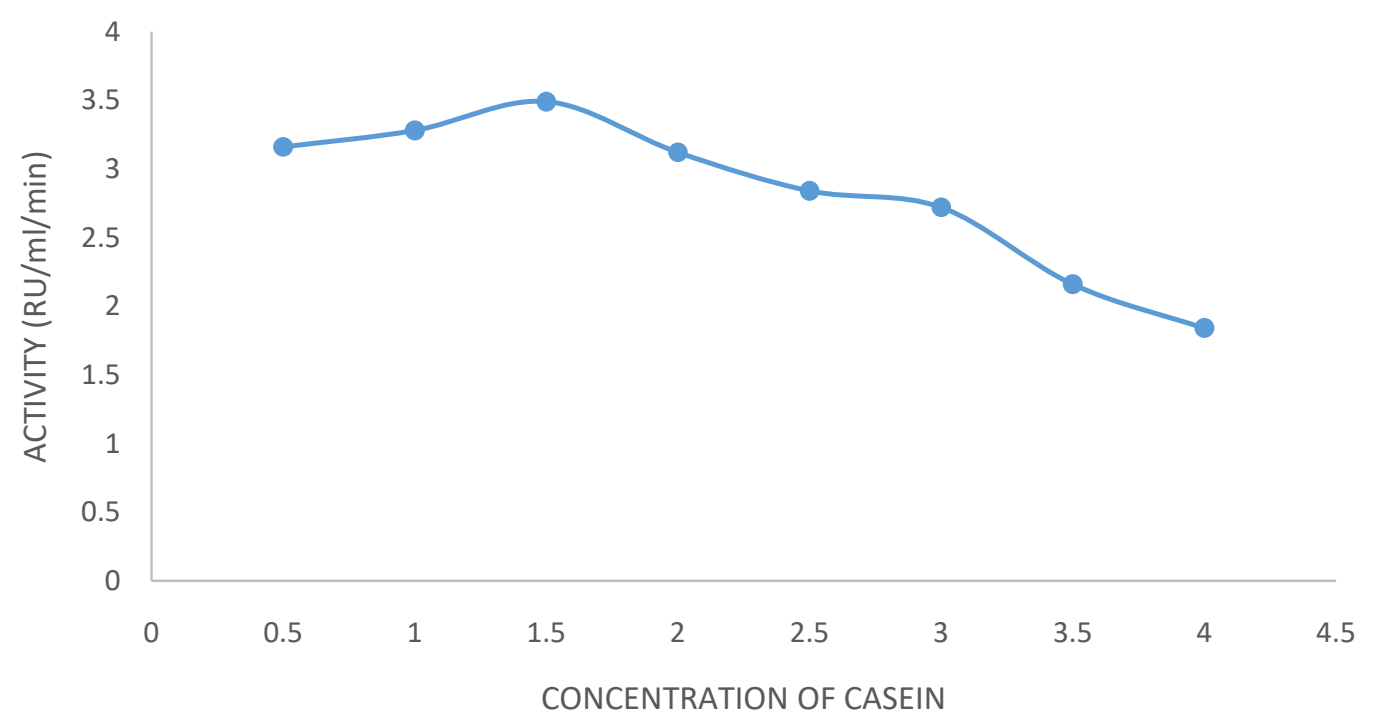

Figure 7. Effect of Different Concentrations of casein on Rhodanese Production by Bacillus licheniformis 


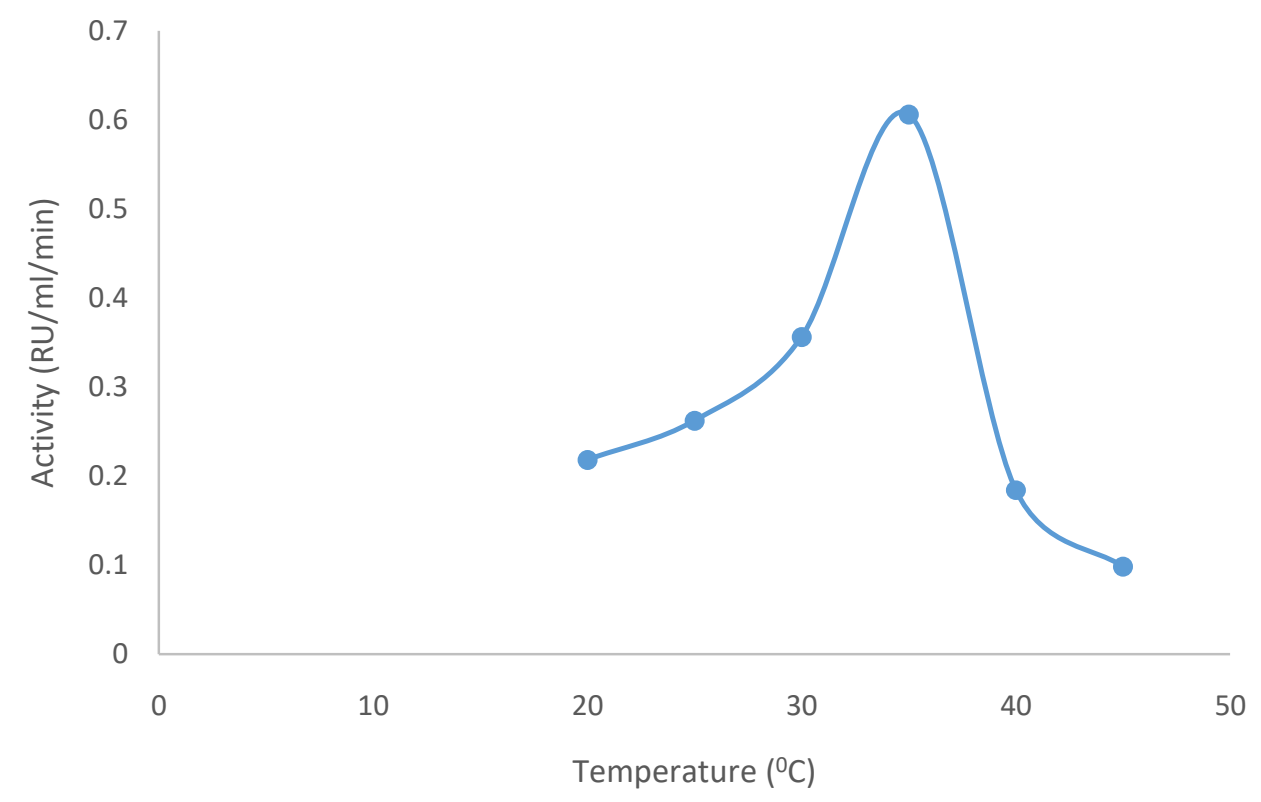

Figure 8. Effect of temperature on rhodanese production by Bacillus licheniformis

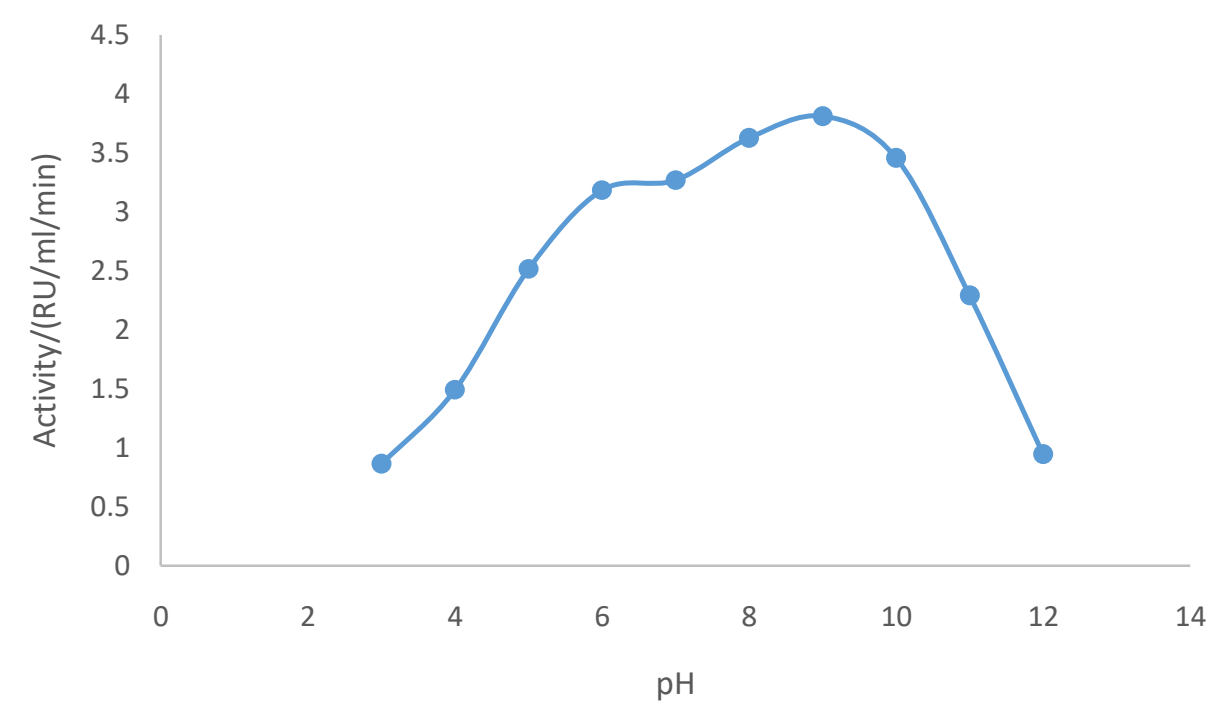

Figure 9. Effect of $\mathrm{pH}$ on rhodanese production by B.licheniformis

\section{Summary of Partial Purification of Rhodanese Obtained From Bacillus licheniformis}

The partial purification of rhodanese was carried out using ammonium sulphate precipitation, ion exchange chromatography and gel filteration. Results for the purification procedures are summarized in Table 3 . The procedures resulted in $13.63 \mathrm{RU} / \mathrm{mg}$ specific activity with a purification fold 5.19 and a percentage yield of $13.69 \%$. 
The protein profile of partially purified rhodanese from Bacillus licheniformis by ion exchange is shown in Figure 10 The eluted protein was concentrated using concentrative dialysis in $50 \%$ glycerol and used for subsequent molecular weight determination on Sephadex G-100 gel filtration chromatography.

Table 3. Summary of Partial Purification Process of Crude Rhodanese Obtained From Bacillus licheniformis

\begin{tabular}{|c|c|c|c|c|c|c|c|c|}
\hline Purification steps & $\begin{array}{l}\text { Volume } \\
(\mathrm{ml})\end{array}$ & $\begin{array}{l}\text { Protein } \\
(\mathrm{mg} / \mathrm{ml})\end{array}$ & $\begin{array}{l}\text { Activity } \\
\text { (RU) }\end{array}$ & $\begin{array}{l}\text { Total } \\
\text { protein }\end{array}$ & $\begin{array}{l}\text { Total } \\
\text { activity }\end{array}$ & $\begin{array}{l}\text { Specific } \\
\text { activity }\end{array}$ & $\begin{array}{l}\% \\
\text { yield }\end{array}$ & $\begin{array}{l}\text { Purification } \\
\text { fold }\end{array}$ \\
\hline Crude enzyme & 50.00 & 1.11 & 2.93 & 55.70 & 146.28 & 2.63 & 100.0 & 1.00 \\
\hline $\begin{array}{l}85 \% \text { ammonium } \\
\text { sulphate } \\
\text { precipitation }\end{array}$ & 20.00 & 1.01 & 2.96 & 20.25 & 59.08 & 2.92 & 40.39 & 1.11 \\
\hline $\begin{array}{l}\text { CM sephadex C- } \\
50 \text { iron exchange } \\
\text { chromatography }\end{array}$ & 10.00 & 0.04 & 0.48 & 0.39 & 4.77 & 12.23 & 3.26 & 4.66 \\
\hline $\begin{array}{l}\text { Sephadex G-100 } \\
\text { gel filteration }\end{array}$ & 7.00 & 0.21 & 2.92 & 1.50 & 20.42 & 13.63 & 13.96 & 5.19 \\
\hline
\end{tabular}

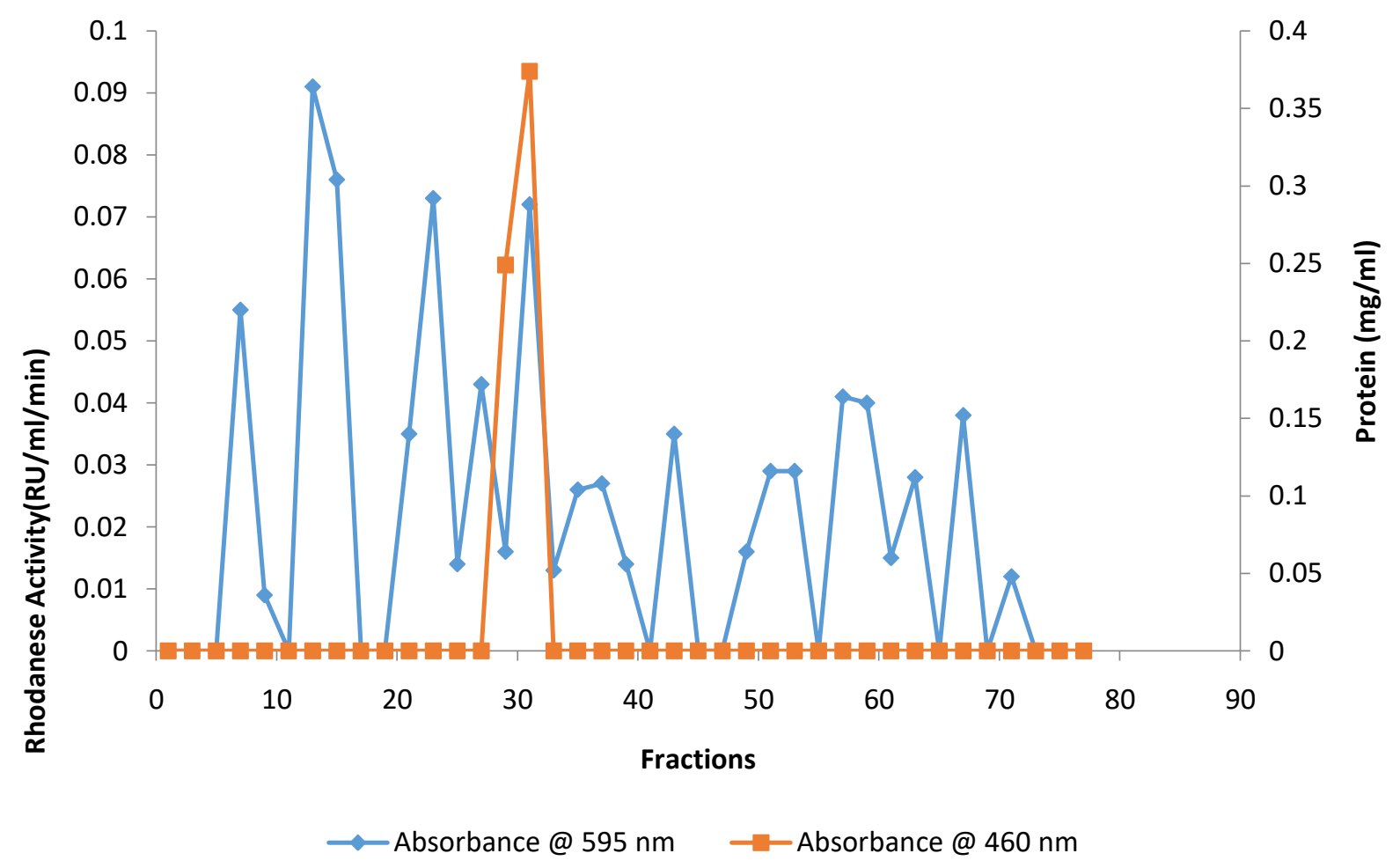

Figure 10. Separation by Ion-Exchange Chromatography on CM-Sephadex C-50 of Partially Purified Rhodanese from Bacillus licheniformis

Protein

Rhodanese Activity 


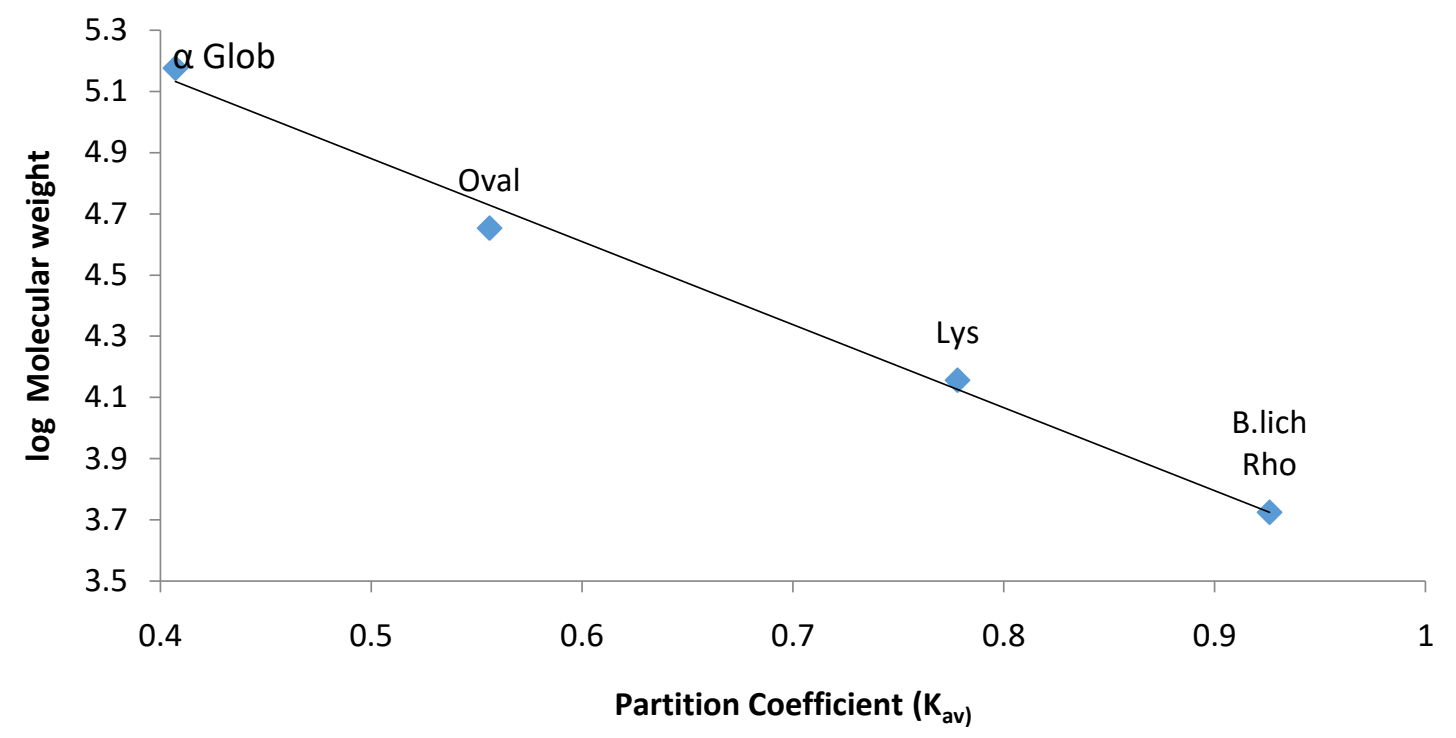

Figure 11a. Calibration Curve for the Determination of Native Molecular Weight of Partially Purified Rhodanese from Bacillus licheniformis

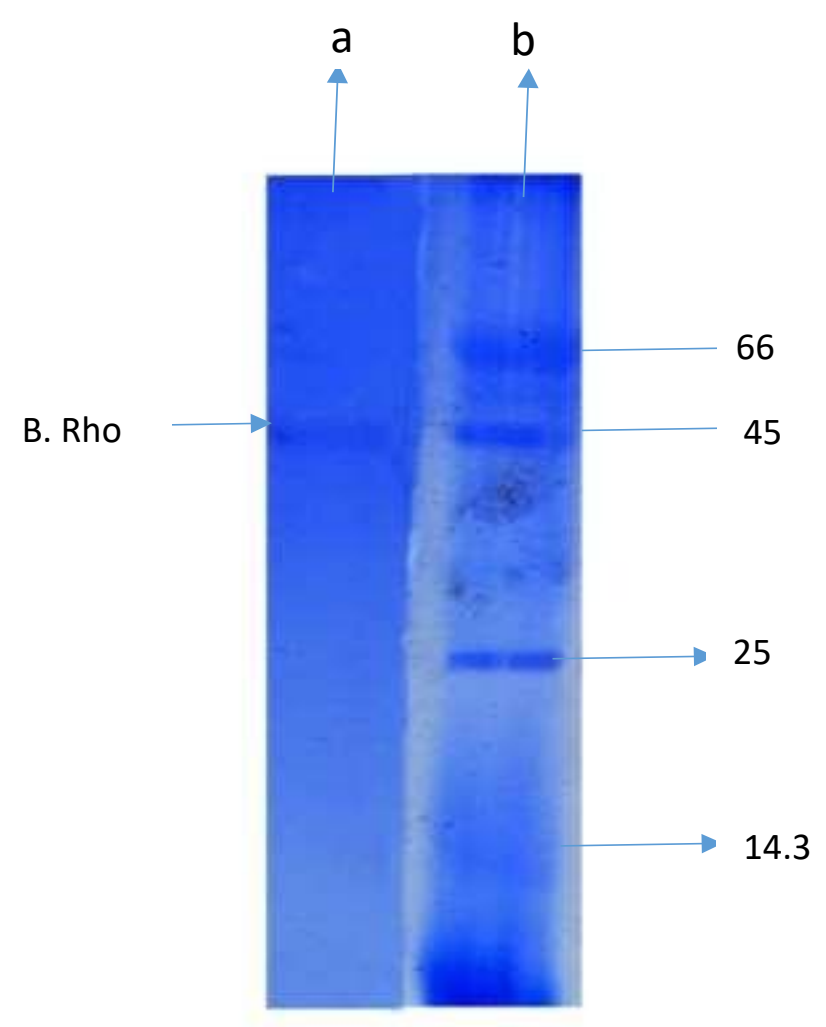


Figure 11b, SDS-PAGE for the Determination of Subunit Molecular Weight of Rhodanese from Bacillus licheniformis. Lane A = Purified rhodanese from the Microorganism Bacillus licheniformis. Lane B = Standard Proteins; The standard molecular weight markers include: $\mathrm{i}=\mathrm{BSA}(66.0 \mathrm{kDa})$, ii = Ovalbumin $(45.0 \mathrm{kDa})$, iii $=$ Chymotrypsin $(25 \mathrm{kDa})$, and iv = Lysozyme $(14.3 \mathrm{kDa})$. B. RHO= Bacillus licheniformis. Rhodanese

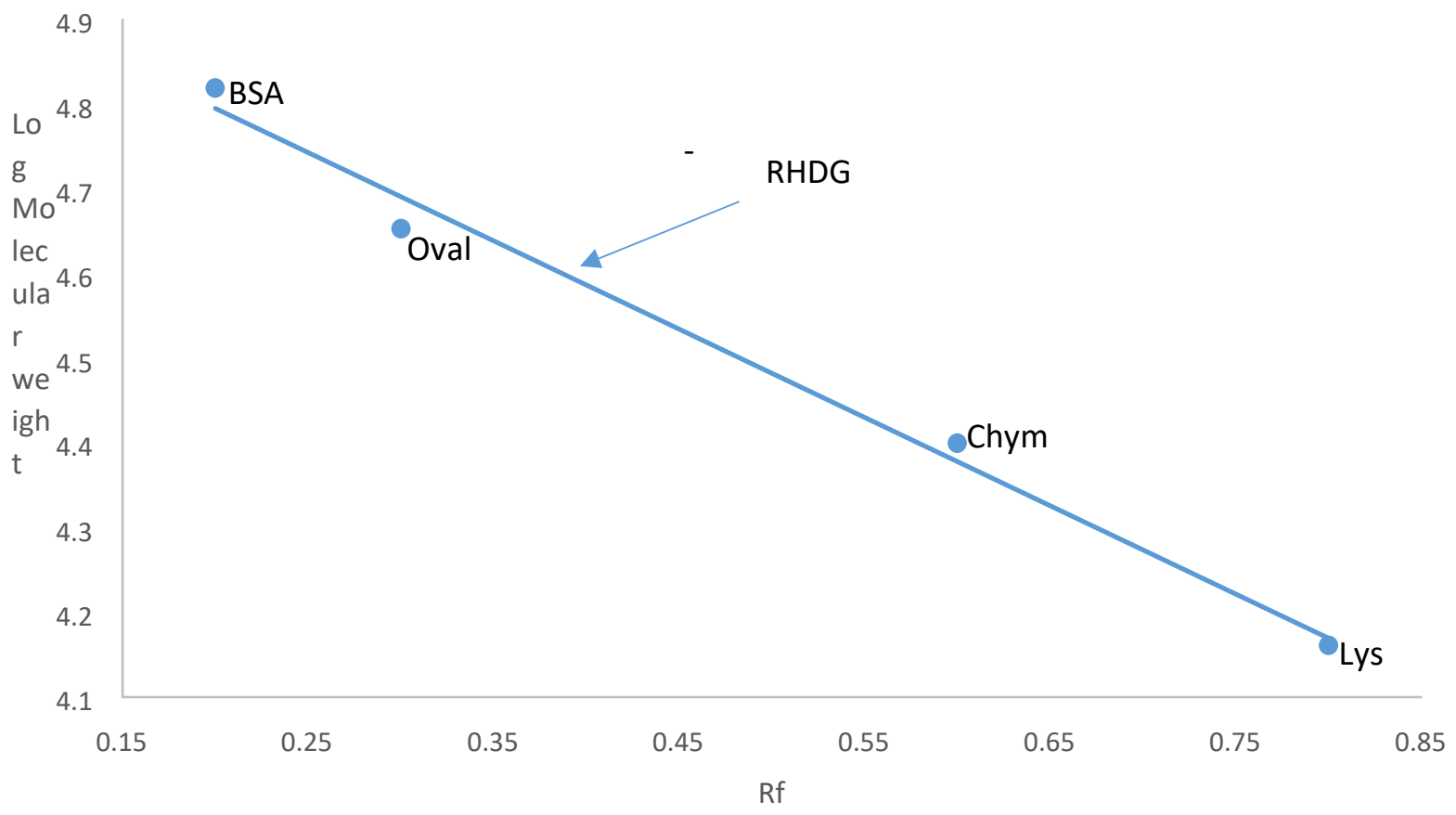

Figure 11c, Calibration Curve for the Determination of Subunit Molecular Weight of Rhodanese Bacillus licheniformis. The subunit molecular weight of the purified enzyme was determined using sodium dodecyl sulphate polyacrylamide gel electrophoresis (SDS-PAGE). BSA (bovine serum albumin; 66, 000 dalton) Oval (Ovine albumin; 45, 000 dalton) Chymo (Chymotrypsin; 25, 000 dalton) Lys (Lysozyme; 14, 500 dalton) 


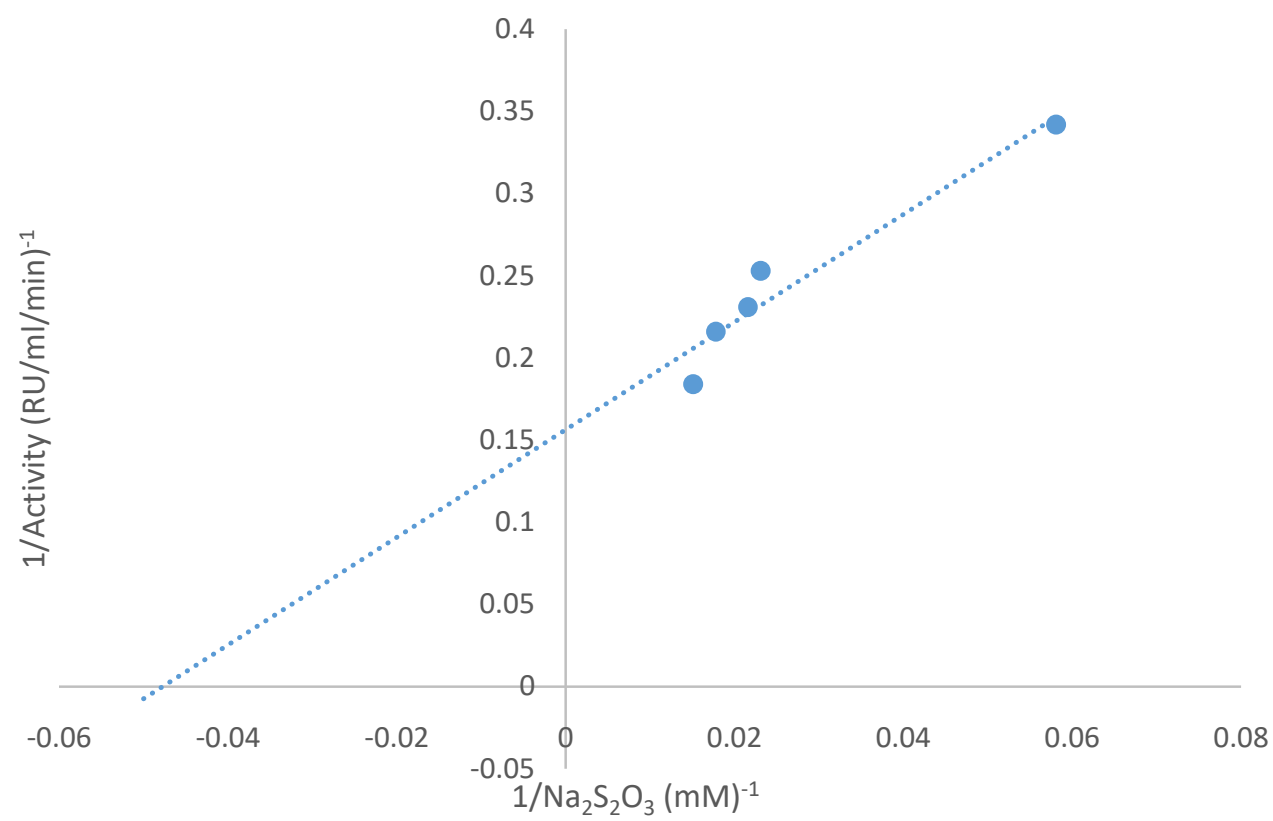

Figure 12. Lineweaver-Burk Plot for Varying Concentration of Sodium Thiosulphate Lineweaver-Burk plot of 1/V against $1 / \mathrm{S}$ at varying concentrations of $\mathrm{Na}_{2} \mathrm{~S}_{2} \mathrm{O}_{3}$ Between $5 \mathrm{mM}$ and $50 \mathrm{Mm}$ and a constant concentration of KCN at $25 \mathrm{mM}$

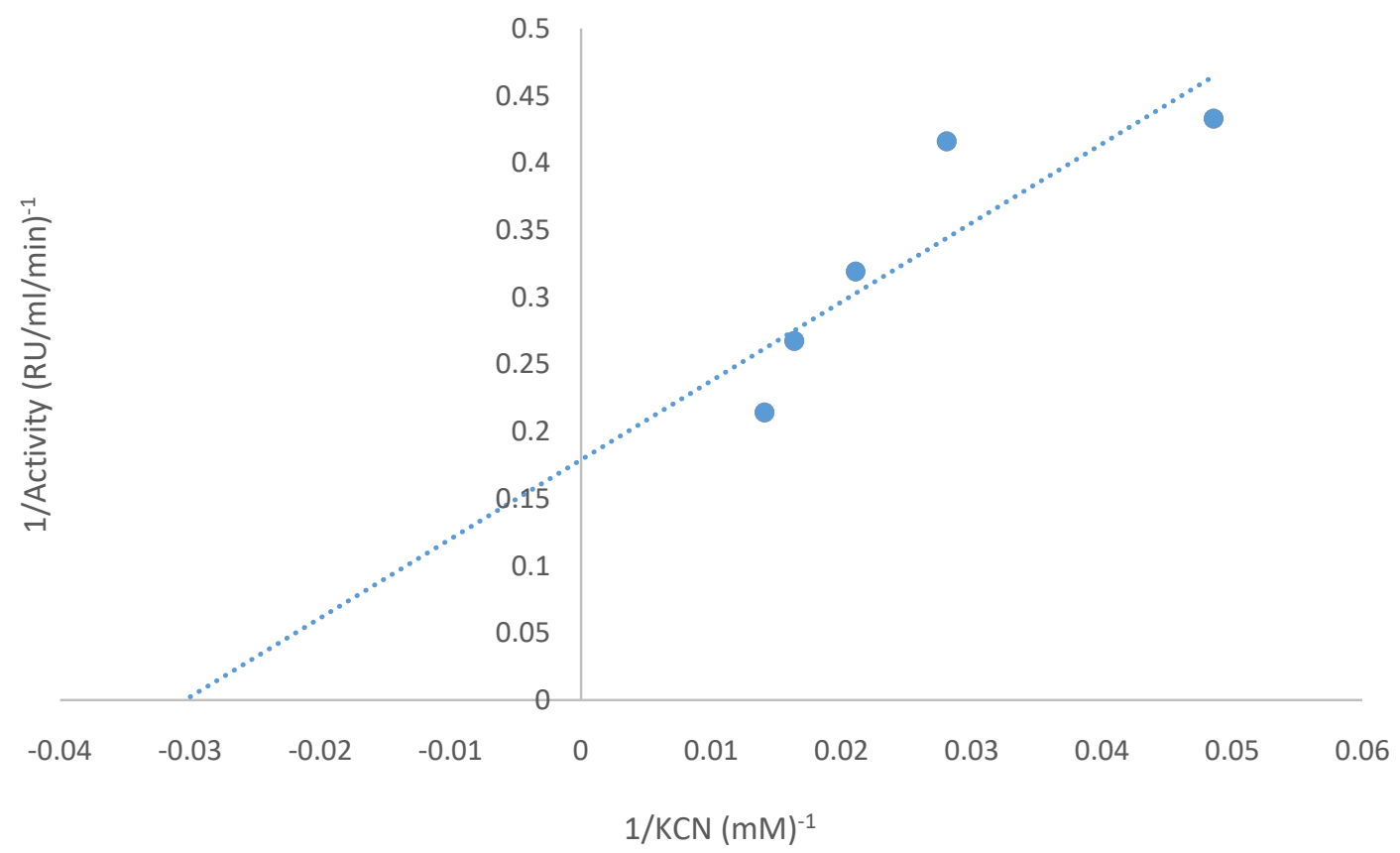

Figure 13. Lineweaver-Burk Plot for Varying Concentration of Potassium Cyanide Lineweaver-Burk plot of 1/V against $1 / \mathrm{S}$ at varying concentrations of KCN Between $5 \mathrm{mM}$ and $50 \mathrm{Mm}$ and a constant concentration of $\mathrm{Na}_{2} \mathrm{~S}_{2} \mathrm{O}_{3}$ at $25 \mathrm{mM}$ 
Table 4. Summary of Kinetic Parameters of Partially Purified Rhodanese from Bacillus licheniformis with KCN and $\mathrm{Na}_{2} \mathrm{~S}_{2} \mathrm{O}_{3}$ Substrates

$\begin{array}{ccc}\text { Substrate } & \mathrm{K}_{\mathrm{m}}(\mathrm{mM}) & \mathrm{V}_{\max }(\mathrm{RU} / \mathrm{ml} / \mathrm{min}) \\ \mathrm{KCN} & 32.90 & 5.60 \\ \mathrm{Na}_{2} \mathrm{~S}_{2} \mathrm{O}_{3} & 21.00 & 6.40\end{array}$

Table 5. Result of Different substrates on Partially Purified Rhodanese From Bacillus licheniform

$$
\text { Sulphur Compounds } \quad \% \text { specificity }
$$

$\begin{array}{cc}\text { Sodium thiosulphate }\left(\mathrm{Na}_{2} \mathrm{~S}_{2} \mathrm{O}_{3}\right) & 100.00 \\ \text { Sodium metabissulphite }\left(\mathrm{Na}_{2} \mathrm{~S}_{2} \mathrm{O}_{5}\right) & 15.08 \\ \text { Ammonium persulphate }\left(\left(\mathrm{NH}_{4}\right)_{2} \mathrm{~S}_{2} \mathrm{O}_{8}\right) & 23.65 \\ \text { 2-mercaptoethanol }\left(\mathrm{CH}_{2}(\mathrm{SH}) \mathrm{CH}_{2}(\mathrm{OH})\right. & 15.83 \\ \text { Sodium sulfite } & 22.09\end{array}$

\section{Metal ions on rhodanese activitity}

The results of the effect of metal ions show that the activity of the enzyme was not inhibited by the investigated salts (Table 6).

\section{Influence of Temperature on Partially Purified Rhodanese from Bacillus licheniformis}

The assay was done to investigate the effect of temperature on activity of rhodanese from Bacillus licheniformis showed the enzyme to have its optimum temperature at $50^{\circ} \mathrm{C}$, as shown in Figure 14

\section{Heat Stability Study on Partially Purified Rhodanese from Bacillus licheniformis}

The enzyme was found to be stable at $50^{\circ} \mathrm{C}$ for 30 minutes. Figure 15 . showed the plot of percentage residual activity of the enzyme against time.

Table 6. Result of Metal Ions on Partially Purified Rhodanese from Bacillus licheniformis

ENZYME ACTIVITY (\%)

METALS

$10 \mathrm{mM}$

$\mathrm{CONTROL}$
$\mathrm{KCl}$
$\mathrm{MgCl}_{2}$
$\mathrm{BaCl}_{2}$
$\mathrm{NiCl}_{2}$
$\mathrm{MnCl}_{2}$
$\mathrm{SnCl}$
$\mathrm{NaCl}$

100.00

$73.32 \pm 3.04$

$97.50 \pm 3.04$

$64.65 \pm 0.72$

$82.32 \pm 2.77$

$97.51 \pm 2.01$

$79.74 \pm 0.12$

100.00
100.00

$74.41 \pm 2.42$

$99.81 \pm 2.98$

$80.44 \pm 1.54$

$86.59 \pm 1.66$

$83.98 \pm 0.87$

$93.66 \pm 2.79$

$89.32 \pm 2.63$ 


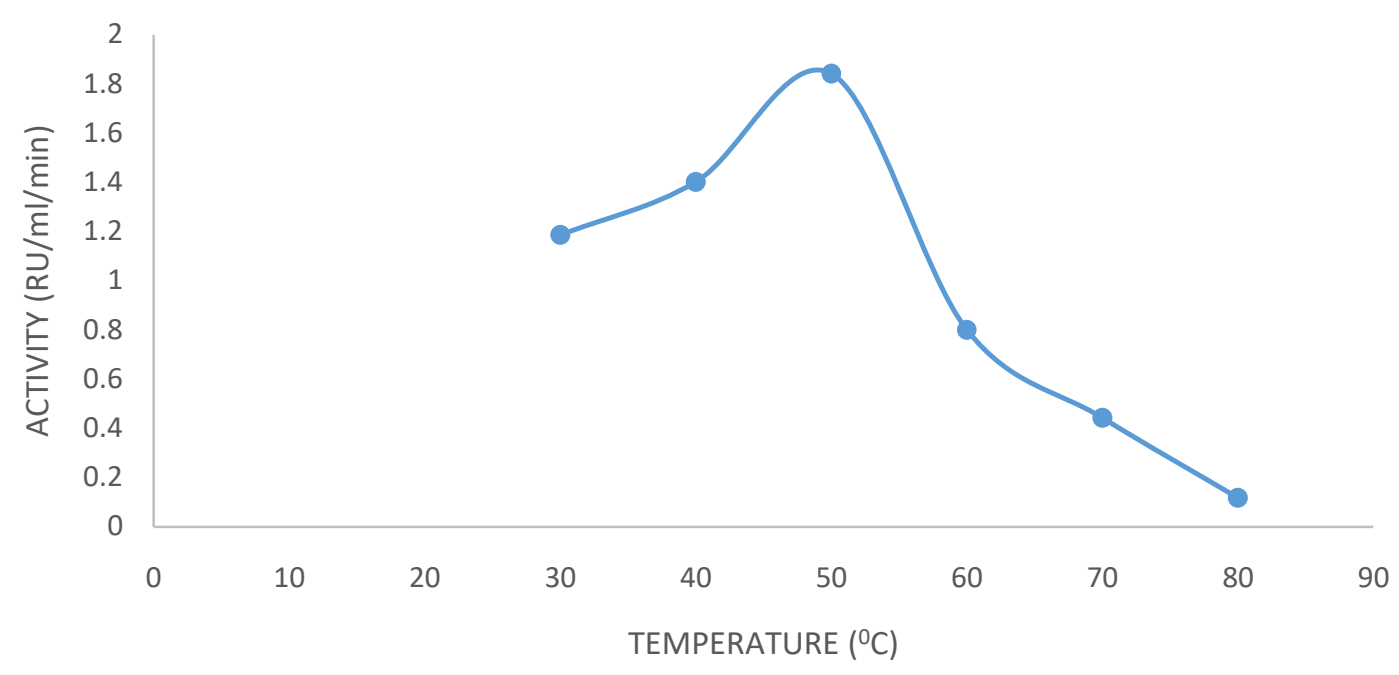

Figure 14. Effect of Temperature on Partially Purified Rhodanese Activity from Bacillus licheniformis

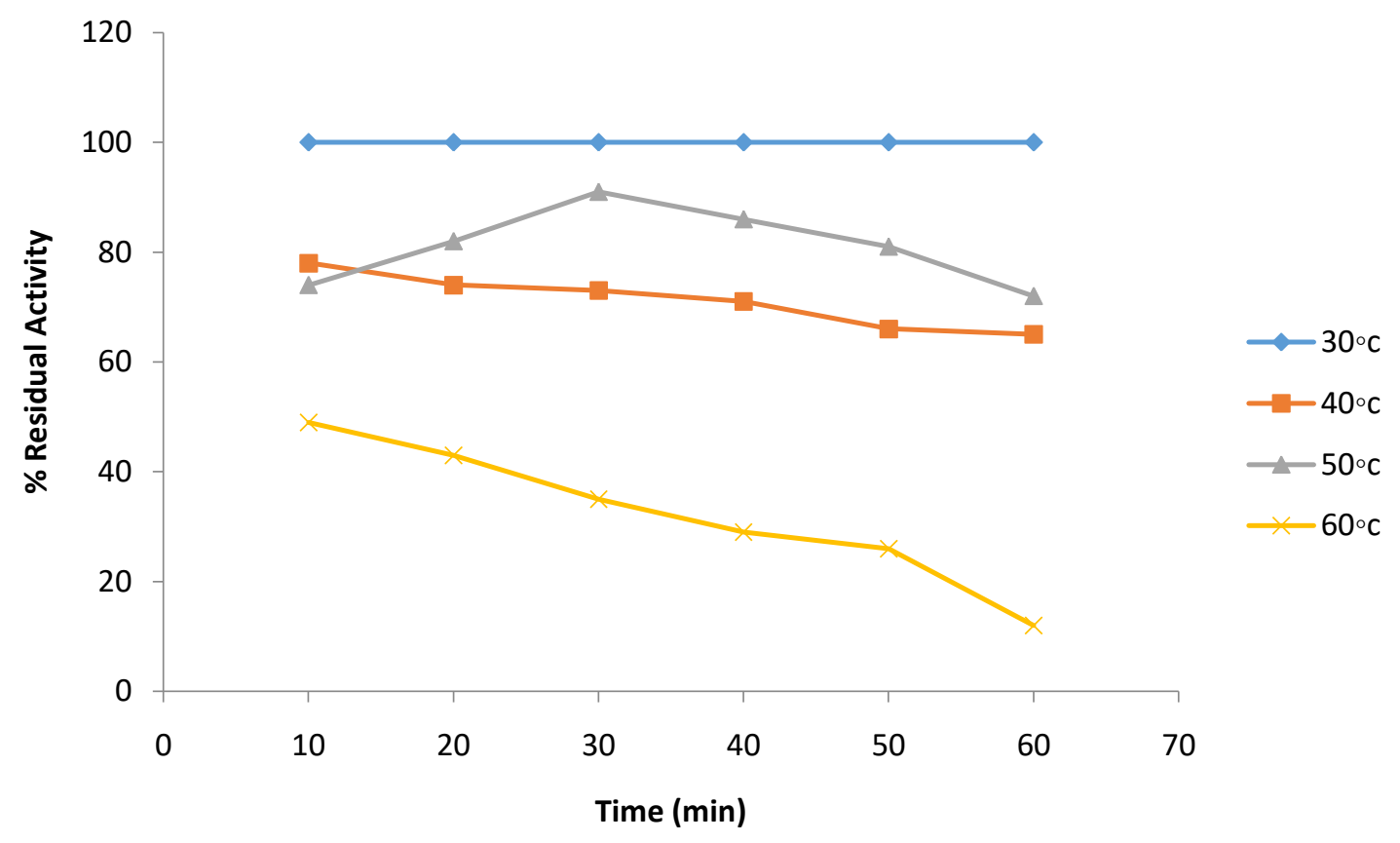

Figure 15. Heat Stability on the Activity of Partially Purified Rhodanese Obtained from Bacillus licheniformis 


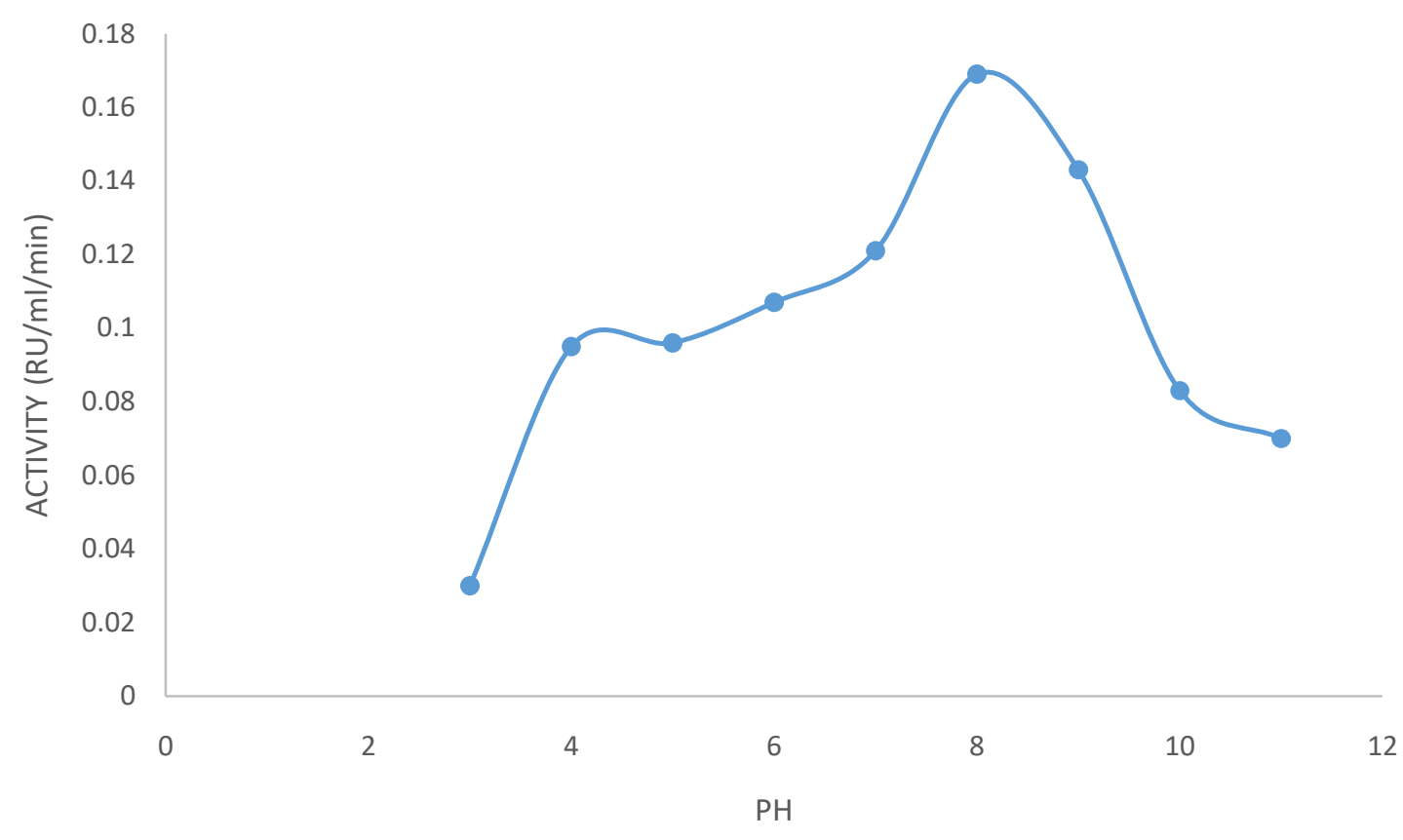

Figure 16. Effect of PH on the partially purified Rhodanese activity from Bacillus licheniformis

\section{Discussion}

The present study made successful attempt to isolate bacteria from the effluents of a steel rolling industry that is capable of producing the enzyme rhodanese. The isolate was gram positive, rod shaped, starch positive, spore forming and catalase positive. The bacterium with the highest activity among all the isolates was identified to be Bacillus licheniformis based on morphological and biochemical characteristics using Bergey's Manual of Determinative Bacteriology.

Production of enzyme such as rhodanese by Bacillus licheniformis is often depends on growth of the bacterium in the appropriate media composition. Rhodanese enzyme in this study is extracellular in nature, the bacteria will accumulate some cell components before the release of enzyme in the log phase, followed by decline in enzyme production during the stationary and death phase respectively. This was observed in Bacillus licheniformis as rhodanese production was maximum at 39 hour with gradual decline. The decline in rhodanese production may be due to exhaustion of the nutrients or accumulation of other products or metabolites which are both inhibitory to the growth of the bacterium and rhodanese production. Goyal et al. (2005) and Prakash et al. (2009) reported that inhibition of enzyme production may occur as a result of catabolic repression by metabolic monosaccharides such as glucose, increase in concentration of protease and rapid change in $\mathrm{pH}$ with the aim of conserving energy by bacteria. The bacterial growth pattern observed in this study was similar to that reported by Hoster et al. (2001) and Oyedeji et al. (2013). Various researches have shown that enzyme synthesis is proportionate with the quality and concentration of carbon and nitrogen sources. These requirements differ from one organism to another (Pandey $e t$ al., 2001; Schnurer and Jarvis 2010).

Naturally, rhodanese have been identified in a variety of bacterial species such as Escherichia coli (Alexander and Volini, 1987; Ray et al., 2000), Azotobacter vinelandii (Chiu et al., 2009) and P. aeruginosa (Ryan and Tilton, 1977; Cipollone et al., 2004).

The optimum nutritional requirement for rhodanese production was determined to obtain maximum enzyme production by Bacillus licheniformis. The effect of different nitrogen sources $(1 \%$ and $0.5 \% \mathrm{w} / \mathrm{v})$ on rhodanese production by Bacillus licheniformis was evaluated using submerged fermentation. The enzyme evaluation indicated that casein gave the maximum activity of the nitrogen sources utilized by Bacillus 
licheniformis in the production of rhodanese with an activity of $3.49 \mathrm{RU} / \mathrm{ml} / \mathrm{min}$ and when their concentrations were varied they gave optimum activity at $1.5 \mathrm{~g} / \mathrm{dm}^{3}$.

Temperature is a vital environmental factor which controls the growth and production of metabolites by microorganisms and this usually varies from one organism to another (Ehigie et al., 2015). Bacterial rhodaneses are produced at much wider range of temperature. In the result of Panos and Bellini it was reported that cyanide microbial activities increase as the temperature increases to $37^{\circ} \mathrm{C}$ (Panos et al., 1999). However, in this study, the optimum temperature for the production of rhodanese was observed to be $35^{\circ} \mathrm{C}$.

The source of carbon available for rhodanese producing bacteria is worthy of note owing to the fact that it is one of the basic requirements for growth and enzyme synthesis. The present study investigated the best carbon source for rhodanese production, potassium cyanide was found to have the highest activity of $3.14 \mathrm{RU} / \mathrm{ml} / \mathrm{min}$.

The result in this study showed that $(0.8 \%)$ potassium cyanide composition of the enzyme production medium produced highest enzyme activity of $3.34 \mathrm{RU} / \mathrm{ml} / \mathrm{min}$ which is very close to $3.21 \mathrm{RU} / \mathrm{ml} / \mathrm{min}$ obtained with $0.25 \%$. This is a clear indication that though different percentage of potassium cyanide composition may be used, $0.8 \%$ is the most suitable.

The optimum $\mathrm{pH}$ for the production of Bacillus licheniformis rhodanese is 9.0 with enzyme activity of 3.81 $\mathrm{RU} / \mathrm{ml}$. Schraft et al. (2006) reported Bacillus licheniformis as an organism with $\mathrm{pH}$ range of 4.3-9.3.This is in accordance with the result of Panos et al. (1999) who had reported 9.0 for optimum microbial cyanide degradation.

Rhodanese was produced under optimized conditions and harvested from the cultured broth for purification. Several methods have been used for the purification of rhodanese from various sources and the method used in this study for the purification of rhodanese from Bacillus licheniformis is similar to those of previous researchers (Cosby and Summer, 1945; Sorbo, 1953; Westley and Green, 1973). Extraction of enzyme was carried out by centrifugation of the cell broth at $12000 \mathrm{rpm}$ for $15 \mathrm{~min}$ to obtain a cell free broth and was purified by a three-step procedure. The cell free broth was precipitated with $85 \% \mathrm{w} / \mathrm{v}$ ammonium sulphate precipitation. The rhodanese from Bacillus licheniformis was further purified by ion exchange chromatography on CM-Sephadex and finally by gel filteration on Sephadex G-100. The result showed a specific activity of $13.63 \mathrm{RU} / \mathrm{mg}$ with a purification fold of 5.19 and a percentage yield of $13.96 \%$. Specific activity of different values from different sources has been reported for rhodanese. Agboola and Okonji (2004) also reported a value of $131 \mathrm{RU} / \mathrm{mg}$ for rhodanese from the fruit bat liver, while Fagbohunka et al. (2004) obtained a value of $20.1 \mathrm{RU} / \mathrm{mg}$ for Giant African snail. Akinsiku et al. (2010) obtained a value of 73 and $72 \mathrm{RU} / \mathrm{mg}$ for catfish rhodanese I (cRHDI) and catfish rhodanese II (cRHDII) respectively. Okonji et al. (2011) obtained a value of $8.4 \mathrm{RU} / \mathrm{mg}$ for mudskipper liver rhodanese. Chew et al. (1972) obtained a yield of 7.8 and Ehigie et al. (2015) reported a percentage yield of 8.78\%.

Native molecular weight of the enzyme was determined using gel filtration on Sephadex G-100. The molecular weight of the rhodanese was 34,440 Dalton. In general, a survey showed that the molecular weight of rhodanese falls between 31, 000 to 37, 000 Dalton (Lee et al., 1995; Agboola and Okonji, 2004; Akinsiku et al., 2010). An apparent molecular weight of 34, 500 Dalton and 36, 800 Dalton were reported for catfish rhodanese I (cRHD I) and catfish rhodanese II (cRHD II) respectively from the liver of African catfish (Clarias gariepinus) (Akinsiku et al., 2010). Agboola and Okonji (2004) reported a molecular weight of 35,700 Dalton for rhodanese from the fruit bat liver. Sorbo (1953b) reported a molecular weight of 37,000 Dalton for bovine liver rhodanese. In 1995, Lee et al. (1995) reported a molecular weight of 34,800 Dalton for the mouse liver rhodanese and Nagahara and Nishino (1996) obtained a molecular weight of 34,000 Dalton for rat liver rhodanese.

The kinetic parameters $\left(\mathrm{K}_{\mathrm{m}}\right.$ and $\left.\mathrm{V}_{\max }\right)$ for potassium cyanide and sodium thiosulphate. Oyedeji et al. (2012) reported that, the $\mathrm{Km}$ values for $\mathrm{KCN}$ and $\mathrm{Na}_{2} \mathrm{~S}_{2} \mathrm{O}_{3}$ as substrates for Pseudomonas aeruginosa rhodanese were 12.5 and $0.0066 \mathrm{mM}$, respectively, while the Km values for the same substrates for Bacillus brevis rhodanese were 3.12 and $11.1 \mathrm{mM}$. Keith et al. (1987) reported the apparent $\mathrm{K}_{\mathrm{m}}$ values of $78 \mathrm{mM}$ and $17 \mathrm{mM}$ for potassium cyanide and sodium thiosulphate respectively for rhodanese from Escherichia coli. Agboola and Okonji (2004) also reported $\mathrm{K}_{\mathrm{m}}$ values of $13.5 \mathrm{mM}$ and $19.15 \mathrm{mM}$ for potassium cyanide and sodium thiosulphate respectively for rhodanese from fruit bat liver, while Hossein and Reza (2011) reported apparent $\mathrm{K}_{\mathrm{m}}$ values of $36.81 \mathrm{mM}$ and $19.84 \mathrm{mM}$ for potassium cyanide and sodium thiosulphate respectively for rhodanese from rainbow trout liver. $K_{m}$ values for KCN and $\mathrm{Na}_{2} \mathrm{~S}_{2} \mathrm{O}_{3}$ were $32.9 \mathrm{mM}$ and $21.0 \mathrm{mM}$, and the $V_{\max }$ values for these substrates $\left(\mathrm{KCN}\right.$ and $\mathrm{Na}_{2} \mathrm{~S}_{2} \mathrm{O}_{3}$ ) were $5.6 \mathrm{mM}$ and $6.4 \mathrm{mM}$, respectively for Bacillus licheniformis. The result from $\mathrm{k}_{\mathrm{m}}$ indicates that the affinity of the Bacillus licheniformis enzyme for these substrates is higher which suggested a possible efficient cyanide catalytic 
mechanism. However, it should be noted that cyanide detoxification is a secondary benefit of rhodanese, which has a number of major physiological roles, including the supply of sulphide for the formation of iron-sulphur centres for the electron transport chain.

Different optimum temperatures have been reported for rhodanese from different organisms (Ehigie et al., 2013). Akinsiku et al. (2010) reported $40^{\circ} \mathrm{C}$ for the rhodanese from the liver of the African catfish from Asejire Lake. Himwich and Saunders (1948) also obtained an optimum temperature of between $38^{\circ} \mathrm{C}$ and $40^{\circ} \mathrm{C}$ for bovine liver rhodanese. Agboola et al. (2004) reported $35^{\circ} \mathrm{C}$ for the rhodanese in the cytosolic fraction of fruit bat liver. Ezzi et al.(2003) obtained a wide temperature optimum of 35 to $55^{\circ} \mathrm{C}$ for rhodanese of different strains of Trichoderma. The optimum temperature for Bacillus licheniformis rhodanese was $50^{\circ} \mathrm{C}$ which agree with the report of rhodanese from different sources (Emuebie et al., 2011). Who obtained the optimum temperature of $50^{\circ} \mathrm{C}$ for mudskipper liver rhodanese, Sorbo (1953) reported an optimum temperature of $50^{\circ} \mathrm{C}$ for bovine liver rhodanese, while Okonji et al.(2011) obtained an optimum temperature of $50^{\circ} \mathrm{C}$ for mudskipper liver rhodanese. The heat stability showed that the enzyme is stable at $50^{\circ} \mathrm{C}$ for 30 minutes

As shown above, optimum $\mathrm{pH}$ for Bacillus licheniformis rhodanese was 8.0. This value is in line with the values found for rhodanese of bovine liver (between 8.0 and 9.0) (Sorbo, 1953), mouse liver (9.4) (Lee et al., 1995), tapioca leaf (10.2-11) (Chew et al., 1972), fruit bat liver (9.0) (Agboola et al., 2004), and mudskipper liver (8) (Okonji et al., 2011). Akinsiku working on the African catfish liver (6.5), obtained a high $\mathrm{pH}$ value of 6.5, (Akinsiku et al., 2010) which is very close to the $\mathrm{pH}$ optimum of Bacillus licheniformis rhodanese. Different optimum $\mathrm{pH}$ values in the range of 8.0 to 11.0 have been reported for different organisms (Lee et al., 1995; Saidu, 2004). These results are in agreement with results reported for rhodaneses from different sources.

Bacillus licheniformis rhodanese was inactivated with 2-mercaptoethanol, ammonium persulphate, and sodium metabisulphite but activity was fully restored by addition of sodium thiosulphate. This studies shows that similar molecular properties between Bacillus licheniformis rhodanese and rhodanese from other sources (Westley 1973), and rhodanese enzyme was inactivated by 2-mercaptoethanol in tapioca leaf (Boey and Chew 1976). Okonji et al. (2011) reported the use of different sulphur compounds from a sulphane pool by rhodanese. Other researchers have also shown the specificity of rhodanese for sulphur from thiosulphate source (Lee et al., 1995). Westley (1981) also reported the importance of sulphane sulphur pool in rhodanese cyanide detoxification mechanism.

The results of the inhibition study on the rhodanese from Bacillus licheniformis showed that the salts used did not have any significant effect on the activity of the enzyme. This could be as a result of consistent exposure to these metals due to their presence in the environment. Similar results have also been reported by Fagbohunka et al. (2004) and Okonji et al. (2011) on the rhodanese from the hepatopancrease of giant african snail and liver of mudskipper respectively. Other results showed little variations. Akinsiku et al. (2010) reported that land tortoise liver rhodanese was not affected by $\mathrm{Mn}^{2+}, \mathrm{Co}^{2+}, \mathrm{Sn}^{2+}, \mathrm{Ni}^{2+}$ and $\mathrm{NH}_{4}{ }^{+}$, while $\mathrm{Ba}^{2+}$ and $\mathrm{Zn}^{2+}$ inhibited the enzyme. Agboola and Okonji (2004) and Hossein and Reza (2012) also reported the effect of metals on the fruit bat liver and rainbow trout rhodanese respectively, stating that the inhibition of fruit bat liver and rainbow trout liver rhodanese by $\mathrm{Hg}^{2+}$ and $\mathrm{Ba}^{2+}$ was probably due to the interaction of these metal ions with sulphydryl groups at the enzyme catalytic site or induction changes in the comformation of the enzyme (Ulmer and Vallee, 1972; Lee et al., 1995; Nagahara and Nishino, 1996).

\section{Conclusion}

This study showed the presence of rhodanese activity in Bacillus licheniformis which has similar characteristics to rhodaneses obtained from other sources. The high level of expression of rhodanese in $B$. licheniformis suggests that the enzyme may possess functional cyanide detoxification mechanism, a bioremediation process for the survival of both plants and animals in the environment. Microbial enhancement of this kind is recommended to help in reduction of toxic materials from industrial effluents. Enzymatic degradation of toxic waste in industrial effluents is highly recommended, before been discharged into the stream or river in order to prevent the ecosystem and its environment from being exposed to the toxicity of untreated effluents from metal processing industries 


\section{References}

[1]. Agboola, F. K. and Okonji, R. E. (2004). "Presence of rhodanese in the cytosolic fraction of the fruit bat (Eidolon helvum) liver," Journal of Biochemistry and Molecular Biology, 37 (3): 275-281,

[2]. Akinsiku, O. T., Agboola, F. K., Kuku, A. and Afolayan, A. (2010). "Physicochemical and kinetic characteristics of rhodanese from the liver of African catfish Clarias gariepinus Burchell in Asejire lake," Fish Physiology and Biochemistry. 36 (3): 573-586.

[3]. Aussignargues, C., Giuliani, M., Infossi, P., and Lojou, E. (2012). Rhodanese functions as sulphur supplier for key enzymes in sulphur energy metabolism. Journal of Biological Chemistry 287: 19936-19948.

[4]. Bradford, M. (1976) A Rapid and sensitive method for the quantitation of microgram quantities of protein utilizing the principle of protein-dye binding. Analytical Biochemistry, 72,248-254.

[5]. Buchanan R. E., Gibbons, N. E. (1974). Bergey's manual of Determinative Bacteriology 8th Edition, The Williams and Wilkins company Baltimore USA.

[6]. Cipollone R, Ascenzi P, Frangipani E, Visca P. (2004). Cyanide detoxification by recombinant bacterial rhodanese. Chemosphere 2006; 63: 942-949.

[7]. Dash, R.R., Gaur, A. and Balomajumder C. (2009). Cyanide in industrial wastewater and its removal: A review on biotreatment. Journal of Hazardous Materials 163: 1-11.

[8]. Domenico, B., Daniela, D., Rita, C., Aristodemo, C., Silvia, P., and Martino, B. (2000). The crystal structure of a sulphur transferase from Azotobacter vinelandii highlights the evolutionary relationship between the rhodanese and phosphatase enzymes families. Journal of Molecular Biology 298 (4): 691 - 704.

[9]. Dubey, S. K. \& Holmes, D. S. (1995).Biological cyanide destruction mediated by microorganisms. World Journal of Microbiology Biotechnology 11: 257-265.

[10]. Ehigie O. L., Okonji R. E., Balogun R. O. and K.D.S. Bamitale (2013). Distribution of Enzyme (Rhodanese, 3-Mercaptopyruvate Sulphurtransferase, Arginase And Thiaminase) in Some Commonly Consumed Plant Tubers in Nigeria. Innovative Systems Design andEngineering vol.4, No.9, pp.7-14.

[11]. Ehigie O. L., Okonji R. E., Ehigie F. A., Olapej A.O. and Fagbohunka B.S (2015). Purification and characterization of rhodanese from the leave of bitter melon (Momordica charantia) Vol.3, pp.47-58.

[12]. Eisler. R., Clarke, D. R. Jr., Wiemeyer, S. N.. and Henry, C. J. (1999). Sodium cyanide hazards to fish and other wildlife from gold mining operations. In: Azcue Journal of M, ed. Environmental impacts of mining activities. Berlin, Springer, pp. 55-67.

[13]. Emuebie, O. R., Adedayo, A. H., Adenike, K. and Kayode, A. F. (2011). "Physicochemical properties of mudskipper (Periophthalmus barbarus pallas) liver rhodanese," Australian Journal of Basic and Applied Sciences. 5(8): 507-514.

[14]. Himwich, W. A. and Saunders, J. B. (1948). "Enzymic conversion of cyanide to thiocyanate," American Journal of Physiology, vol. 53, pp. 348-354.

[15]. Lee, C. H., Hwang, J. H., Lee, Y. S. and Cho, K. S. (1995) "Purification and characterization of mouse liver rhodanese," Journal of Biochemistry and Molecular Biology, vol. 28, pp. 170-176

[16]. Lineweaver, H. and Burk, D.(1934) The Determination of Enzyme Dissociation Constants. Journal of American Chemical Society' 56,658 .

[17]. Nagahara, N., and Nishino, T. (1996). Role of Amino acid residues in the active site of rat liver mercaptopyruvate sulphutransferases. Journal of Biological Chemistry. 271 (44): 27395-27401.

[18]. Nandi, D., Horowitz, P., and Westley, J. (2000). Rhodanese as thioredoxin oxidase. International Journal of Biochemistry and Cellular Biology 32: 465-473.

[19]. Okonji, R. E., Adewole, H. A., Kuku, A., and Agboola, F.K. (2011).Physicochemical properties of Mudskipper (periophthalamus barbarous pallas) liver rhodanese. Australian journal of basic and applied sciences

[20]. Oparin, A. I. (1957). The origin of life of earth, Oliver and Boyd, London. 3: 106-108

[21]. Parmar, J.H. (2012). Quantification of metabolism in Saccharomyces cerevisiae under hyperosmotic conditions using elementary mode analysis. J Ind Microbial Biotechnol 39(6):927-41

[22]. Pessi, G. and Haas, D. (2004). Cyanogenesis. InPseudomonas, vol. III, pp. 671-686. Edited by J. L. Ramos. New York: Kluwer Academic/ Plenum Publishers.

[23]. Rawls, R., (1997). Earth is first organics, Chemical Engineering News, American Chemical Society, pp 20-22.

[24]. Ray, R., Padmaya, G., and Balogopalan, C. (2000). Extracellular Rhodanese Production by Rhizopus oryzae. Zentralblatt Mikrobiologie 145 (4): 259-268.

[25]. Sorbo, B. H. (1953b). Crystalline Rhodanese. Enzyme catalyzed reaction. Acta Chemical Scandinavia 7: 1137-1145.

[26]. Ugulava, N.B., Gibney, B.R., and Jarrett, J.T. (2000). Iron-sulphur cluster interconversions in Biotin synthase: dissociation and reassociation of iron during conversion of [2Fe-2S] to [4Fe-4S] clusters. Biochemistry 39: 52065214.

[27]. Zagrobelny, M., Bak, S. and Møller, B. L. (2008). Cyanogenesis in plants and arthropods.Phytochemistry 69: 14571468. 